\title{
Global Food Prices and Domestic Inflation: Some Cross-Country Evidence
}




\title{
WP/15/133
}

\section{IMF Working Paper}

\section{Global Food Prices and Domestic Inflation: Some Cross- Country Evidence}

\author{
by Davide Furceri, Prakash Loungani, John Simon, \\ and Susan Wachter
}

IMF Working Papers describe research in progress by the author(s) and are published to elicit comments and to encourage debate. The views expressed in IMF Working Papers are those of the author(s) and do not necessarily represent the views of the IMF, its Executive Board, or IMF management.
I N
N T E R N A T I O N A L
$M O N E T A R Y$
F U N D 


\title{
IMF Working Paper
}

Research Department

\section{Global Food Prices and Domestic Inflation: Some Cross-Country Evidence \\ Prepared by Davide Furceri (IMF), Prakash Loungani (IMF), John Simon (Reserve Bank of Australia), and Susan Wachter (University of Pennsylvania) ${ }^{1}$}

June 2015

\begin{abstract}
IMF Working Papers describe research in progress by the author(s) and are published to elicit comments and to encourage debate. The views expressed in IMF Working Papers are those of the author(s) and do not necessarily represent the views of the IMF, its Executive Board, or IMF management.
\end{abstract}

\begin{abstract}
This paper provides a broad brush look at the impact of fluctuations in global food prices on domestic inflation in a large group of countries. For advanced economies, we find that these fluctuations have played a significant role over the period from 1960 to the present, but the impact has declined over time and become less persistent. We also find that the more recent global food price shocks occurred in the 2000s had a much bigger impact on emerging than on advanced economies. This larger impact could reflect the larger share of food in the consumption baskets in emerging economies on average than in advanced economies, and less anchored inflation expectations in emerging economies than in advanced economies.
\end{abstract}

JEL Classification Numbers: E31, F41, E50, E52, E60

Keywords: inflation, food prices, pass-through

Author's E-Mail Address: DFurceri@imf.org; PLoungani@imf.org;

simonj@rba.gov.au; wachter@wharton.upenn.edu

\footnotetext{
${ }^{1}$ We also acknowledge the helpful comments of the editor and two anonymous referees. An earlier version of this paper was presented at a conference on causes and consequences of food price volatility hosted by the OCP Policy Center in Rabat, Morocco in February 2014. We are particularly grateful to Saurabh Mishra and Sangyup (Sam) Choi for many helpful discussions and for outstanding assistance with assembling the data set and carrying out the empirical work. The views expressed in the paper are those of the authors and do not represent those of the IMF or the Reserve Bank of Australia.
} 
Contents Page

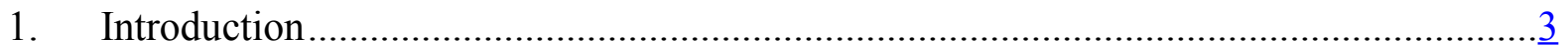

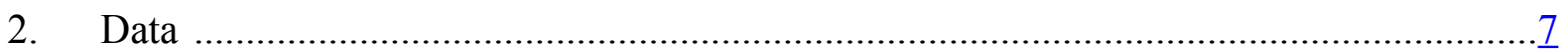

3. Global Food Prices and Inflation: Results from Annual Data ......................................10

4. Evidence from Monthly Data for the 2000s ............................................................ 21

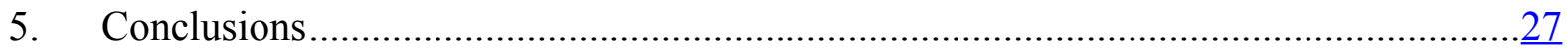

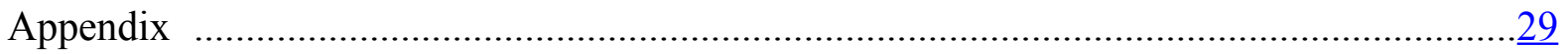

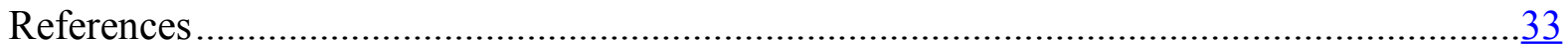

\section{Tables}

1. Baseline Estimates ................................................................................................. 12

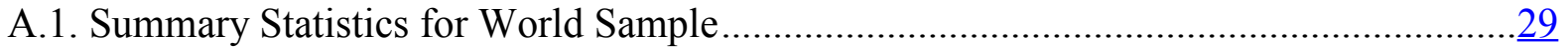

A.2. Summary Statistics by Country .............................................................................. 30

A.3. Summary Statistics on the Monthly Data Set, 2000 to 2013 ........................................

A.4. Economies Included in the Analysis of Inflation Expectations ................................... 32

Figures

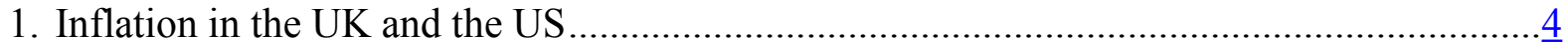

2. Real World Food Prices, 1957-2014 .............................................................................. 6

3. Correlations of Inflation with Food Prices and Excess Money Growth, Annual Data ......... $\underline{8}$

4. Correlations of Inflation with Food Prices, (monthly) 2000-13 .....................................

5. The Impact of Food Price Shocks on Domestic (CPI) Inflation (percentage points)..........11

6. The Impact of Food Price Shocks on Domestic (CPI) Inflation (percentage points), Robustness Checks. .........................................................................................13

7. The Impact of Food Price Shocks on Domestic (CPI) Inflation, 1960-82 vs.1983-2012 (percentage points) ....................................................................................... 15

8. The Impact of Food Price Shocks on Domestic (CPI) Inflation, Assuming Time-Invariant Food Shares (percentage points) .........................................................................16

9. The Impact of Food Price Shocks on Domestic (CPI) Inflation, 1960-82 vs.1983-2012 for the UK and the US (percentage points) ................................................................ 17

10. The Impact of Food Price and Excess Money Shocks on Domestic (CPI) Inflation

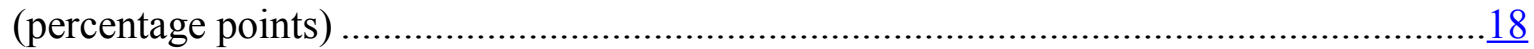

11. The Impact of Food Prices on Domestic (CPI) Inflation, AEs vs. EMs, 1999-2012

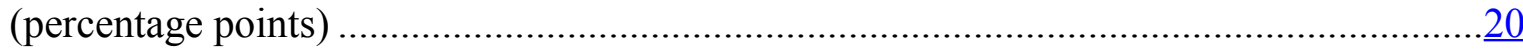

12. Pass-through from World Inflation to Domestic Inflation..........................................22

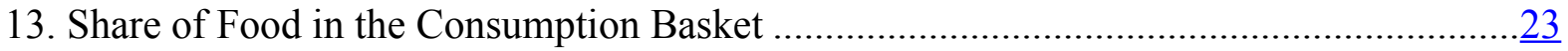

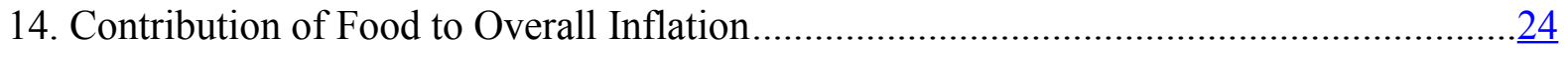

15. Response of Inflation Expectations to Inflation Surprises......................................... 26 


\section{INTRODUCTION}

The extent to which relative price changes can lead to inflation has long been a source of controversy. ${ }^{2}$ In the late 1960 s and early 1970 s, for instance, many observers assigned an important role to food price shocks in the sharp increase in inflation in advanced economies such as the United Kingdom and the United States (see Figure 1). DiCecio and Nelson (2009) cite typical U.K. Treasury analyses of inflation, for example a 1968 document which noted that "the increase in [retail prices] in June was largely the result for higher prices for fresh fruit ... which were only partially offset by lower potato prices." The U.K. Treasury's Economic Progress Report noted in 1978 that there had been a "general realization that inflation could not be simply identified with excess total demand."

Likewise, for the United States, Blinder (1982) argued that "large unavoidable adjustments in relative prices" were the source of much of the inflation of the early 1970s:

"Despite the cacophony of complaints about "ruinous" budget deficits and "excessive" monetary growth ...the dramatic acceleration of inflation between 1972 and 1974 can be traced to rising food prices, rising energy prices, and the end of the Nixon wage-price controls program."

Blinder also argued that the initial impetus for accelerating inflation in 1978 "came mainly from the food sector." He famously concluded that "the 1970 s really were different, and I fail to see why a theory of inflation is more scientific if it ignores this fact." In a recent re-investigation of the same terrain, Blinder and Rudd (2008) conclude that, even using the revised data available at present, "the two OPEC shocks, the two roughly contemporaneous food price shocks, and the removal of wage-price controls in 1973-1974 played starring roles in the macroeconomic events that constituted the Great Stagflation. Money and aggregate demand were, by comparison, bit players."

Blinder and Rudd, however, note that in contrast to the experience of the 1970s, supply shocks since that time have had much less of an impact on U.S. inflation. They suggest that this was due to a number of factors. First, there have been changes in the structure of the U.S. economy. Food accounts for a smaller share of consumption baskets than in the 1970s. There is also greater wage flexibility, so wages absorb more of the supply shocks than in the past (Blanchard and Gali, 2007).

\footnotetext{
2 The controversy is partly reflected in debates between the 'structuralist' and 'monetarist' views of inflation. As Wachter (1979) notes, the essence of the structuralist view is that "relative prices affect the inflation rate." The structuralist view has been prominent in Latin America, with many authors arguing that the source of inflation is an underdeveloped social and economic structure, particularly a relatively backward agricultural sector. In this setting, supply disruptions lead to increases in the price of food which-combined with the downward rigidity of non-food prices - translates into increases in the overall level of prices. In contrast, the monetarist position is "rooted in the belief that ... inflation is the result of continued expansion of aggregate demand (Wachter, 1979)."
} 
Figure 1: Inflation in the UK and the US

Panel A: UK (year on year change in CPI)

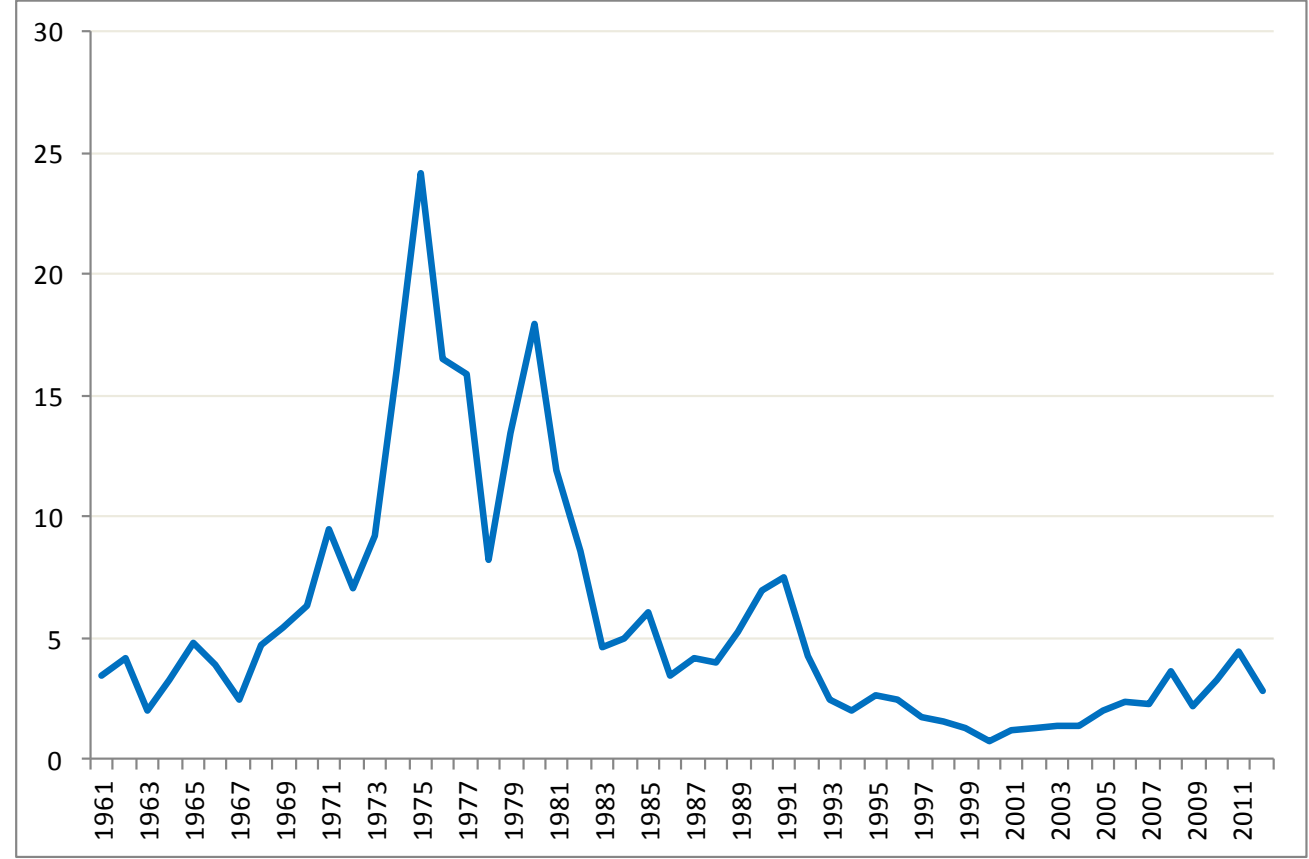

Panel B: US (year on year change in CPI)

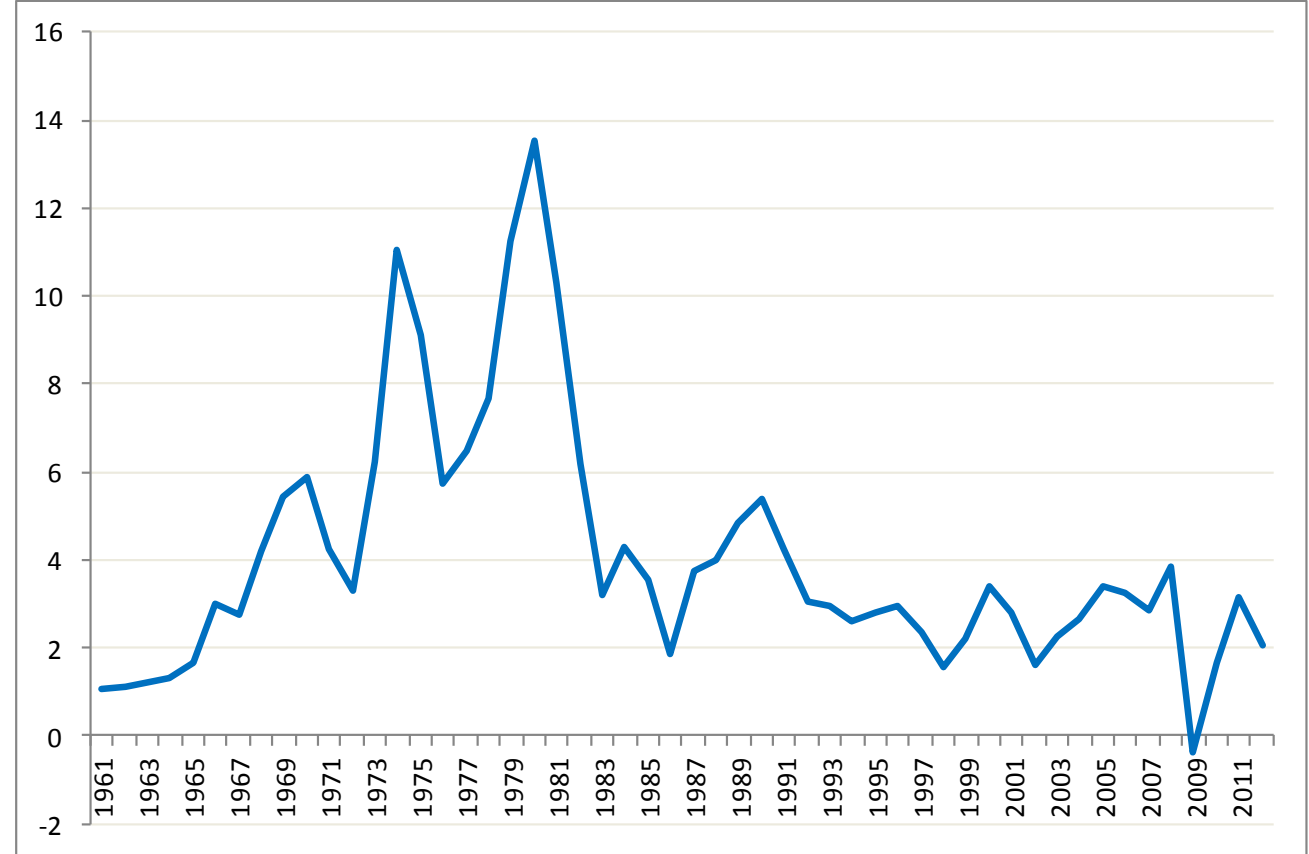

Source: authors' calculations see data appendix. 
Second, there have been changes in the response of monetary policy to supply shocks: "The Fed came to focus more on core inflation and, perhaps, gained anti-inflation credibility that now helps keep expected inflation under control." A similar transformation in the conduct of monetary policy has taken place in the United Kingdom — as documented extensively in Batini and Nelson (2005) — and in many other countries around the globe (Rogoff, 2003).

Third, in contrast to the experience during the 1970s, food price shocks were essentially absent in the 1980s and 1990s — an index of world food prices declined steadily over this period (see Figure 2, Panel A). In the 2000s, however, food prices rose again with sharp spikes in 2004, 2008 and 2012 (Figure 2, Panel B). ${ }^{3}$ These developments, combined with the prospect that food prices could remain elevated for a sustained period, have raised concerns that food prices could again spill over into higher overall inflation. This concern is particularly acute for emerging and developing economies, where the share of food in the consumption baskets remains high and monetary policy may lack the credibility to keep inflation expectations anchored. (In the remainder of the paper, we refer to 'emerging and developing economies' simply as 'emerging economies'.)

Against this context, this paper carries out an empirical exploration of the following questions:

- What role have global food price movements played in domestic inflation since the 1960s?

- Do other advanced economies display the same reduced sensitivity of inflation to global food price movements that Blinder and Rudd found for U.S. data?

- Did the impacts of the food price shocks of the 2000s differ across advanced and emerging economies and what channels have influenced such differences?

Section 2 provides a brief description of the two data sets we use to answer these questions. Section 3 provides evidence from annual data, largely for advanced economies, on the impact of global food prices on inflation and how that impact has declined over time. ${ }^{4}$ Section 4 focuses on the 2000s and compares the inflation experience of advanced and emerging economies. Evidence is provided that food prices have contributed more to inflation in emerging than in advanced economies over this decade and that one reason for this greater impact could be lower credibility of monetary policy in the former group.

\footnotetext{
${ }^{3}$ See Arezki, Hadri, Loungani and Rao (2014) for a discussion of drivers of trends in food and other commodity prices.

${ }^{4}$ For an earlier empirical exploration of this kind, see Loungani and Swagel (2001).
} 
Figure 2: Real World Food Prices, 1957-2014

(Index, 2000=100)

Panel A: 1960-1999

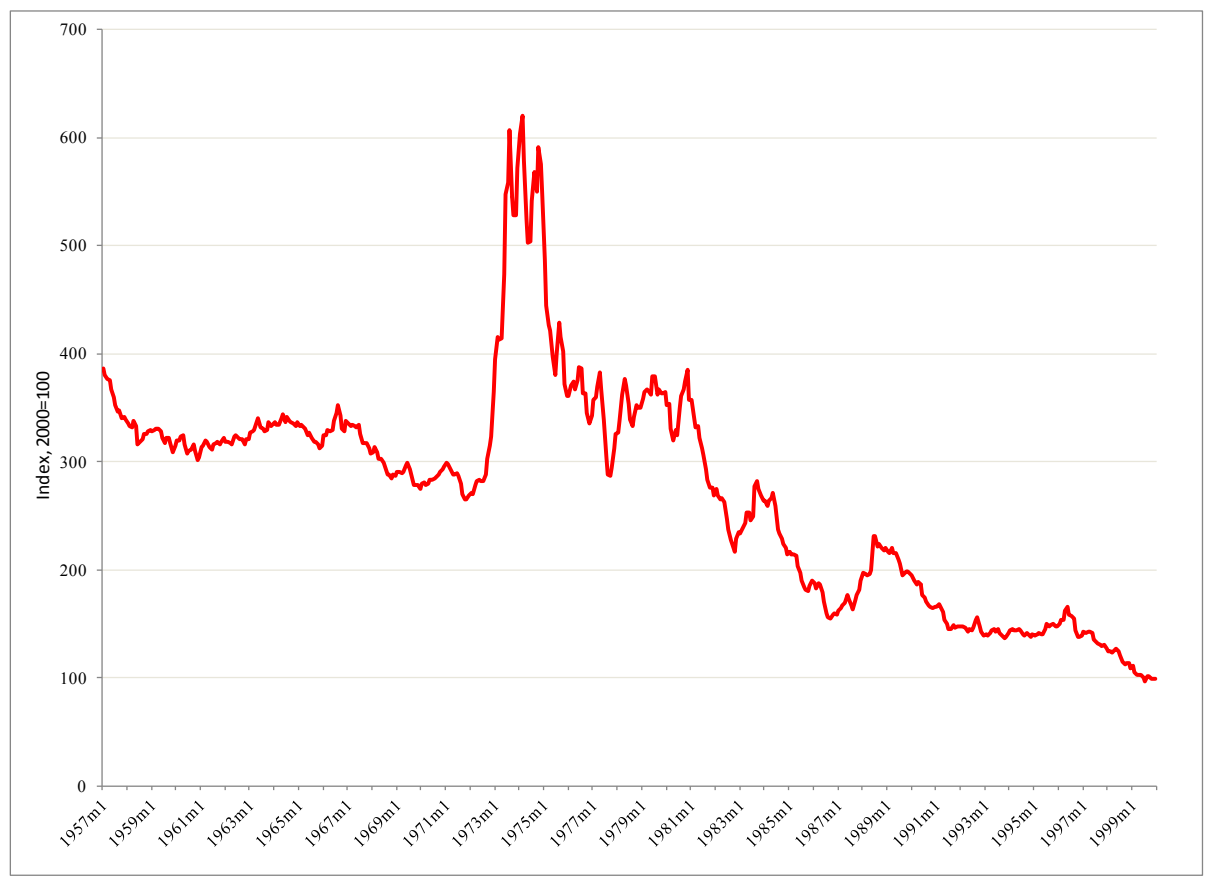

Panel B: 2000-2014

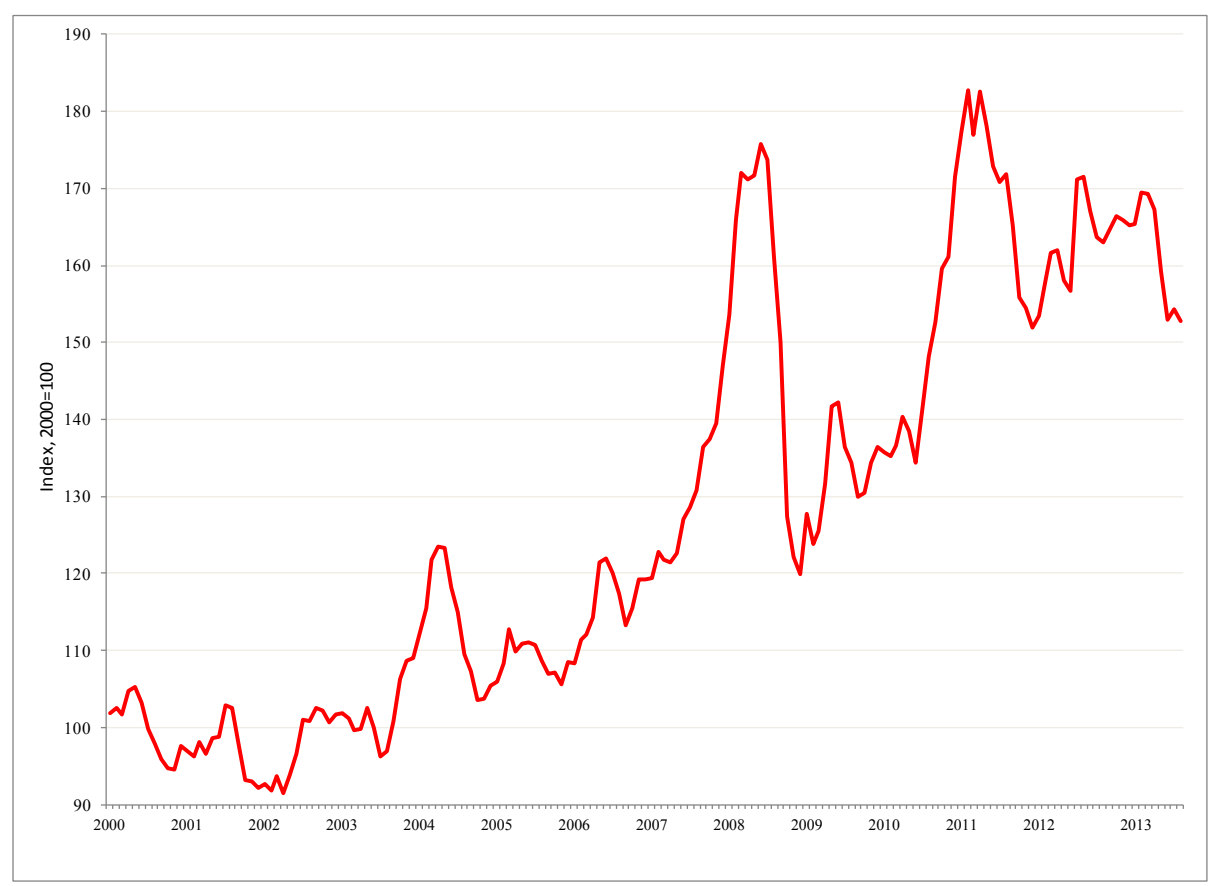

Source: country sources from Haver Analytics. 


\section{DATA}

To answer the three questions posed in the introduction, ideally one would have data that covers both advanced and emerging economies and for a long period of time. Unfortunately, this is not the case. Data for emerging markets is not easily available, does not extend back in time, and there are issues of quality. We try to make a virtue of necessity by assembling two data sets that, taken together, do give us the ability to answer the questions posed. The first data has annual data going back to the 1960s for many advanced economies and a few emerging economies. The second data set has monthly data for the 2000s and covers a large group of advanced and emerging economies; data quality for the latter group remains an issue but is perhaps less acute than data for earlier decades. We use the first data set to see how the impact of food prices on inflation has changed in the advanced economies over time. The second data set is helpful in seeing how the impact of food price shocks differs between advanced and emerging economies in the recent decade and understanding the channels of transmission.

The first data set has annual data for 44 countries. The data appendix presents the sources of data used in the analysis and summary statistics on CPI inflation, food inflation, money growth and nominal GDP growth (see Tables A.1 and A.2). As purely an illustration of the basic properties of the data, the left panel of Figure 3 shows a scatter plot of average CPI inflation and average food inflation, which suggests a modest positive association between the two. The right panel shows that average CPI inflation and average 'excess money' growth — defined as average money growth minus average real GDP growth —also have a positive association. ${ }^{5}$

The economies included in the second data set are listed in Table A.3 in the appendix. This data set consists of monthly data on CPI and food prices for 34 advanced economies and 50 emerging economies over the period 2000-13. Data are taken from Haver Analytics and IMF Primary Commodity Prices. Again, to illustrate the data, Figure 4 shows the positive association between average CPI inflation and food inflation for advanced and emerging economies.

\footnotetext{
${ }^{5}$ See Dwyer and Hafer (1999) and DeGrauwe and Polan (2005) for a discussion of the theoretical underpinnings of the relationship between inflation and excess money growth and some cross-country evidence.
} 
Figure 3: Correlations of Inflation with Food Prices and Excess Money Growth, Annual Data

World, 1960-2012 (means)
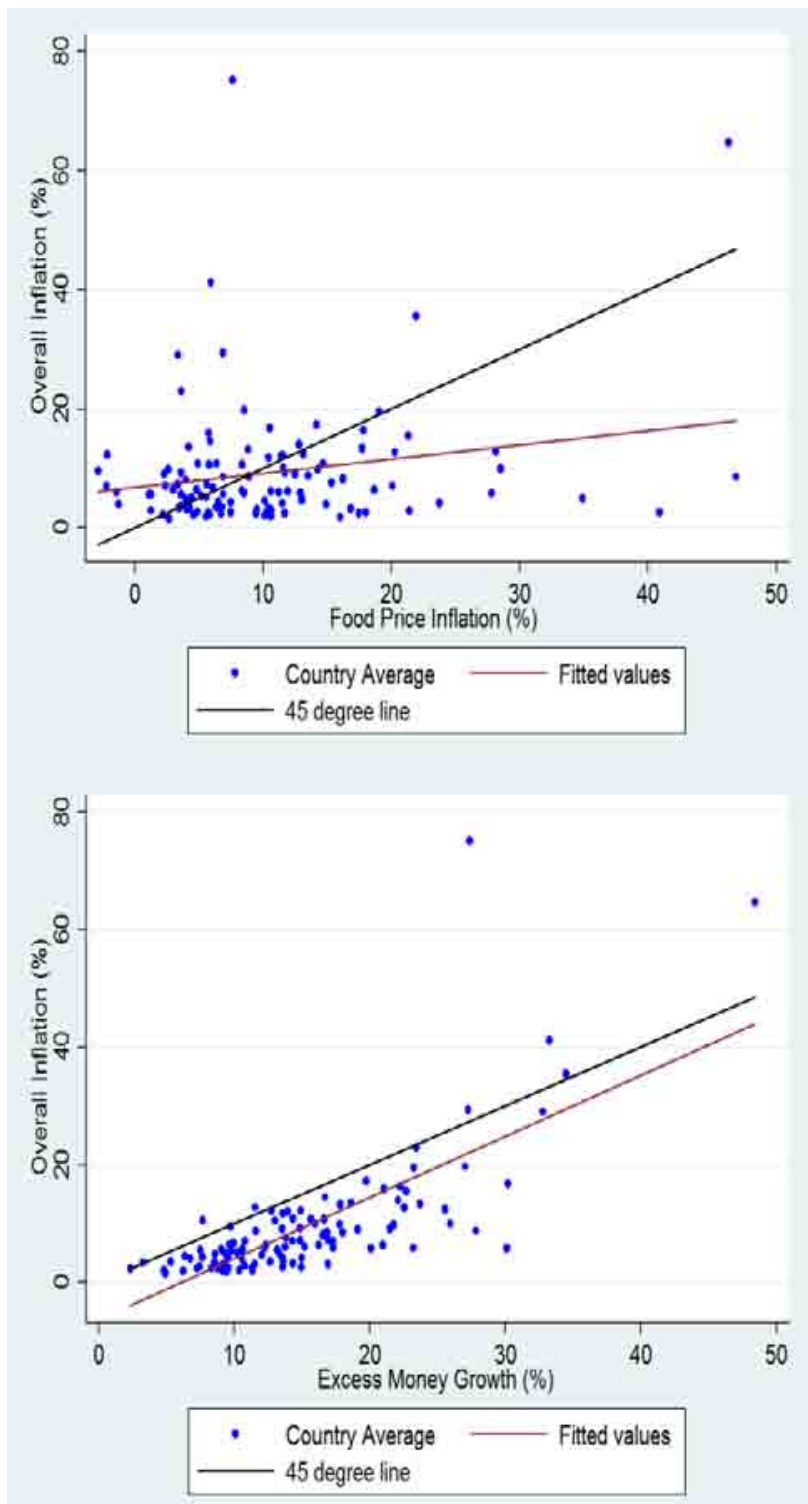

Source: authors' calculations using Haver Analytics.

Notes: Ukraine, Brazil, Bolivia, and Central African Republic are not shown on the graphs above. 
Figure 4: Correlations of Inflation with Food Prices, (monthly) 2000-13

Advanced

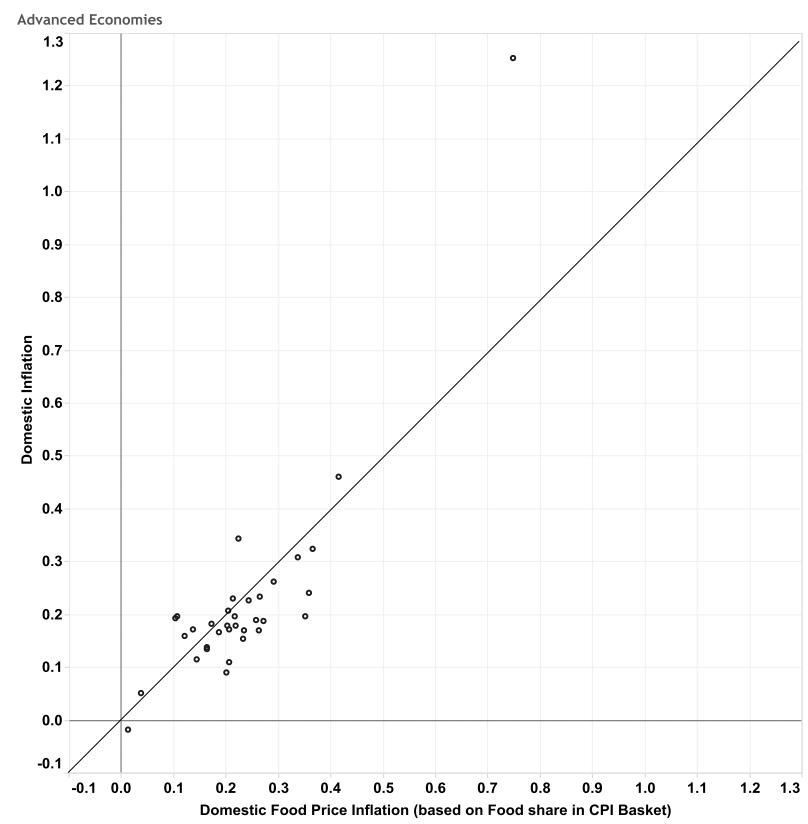

EM's

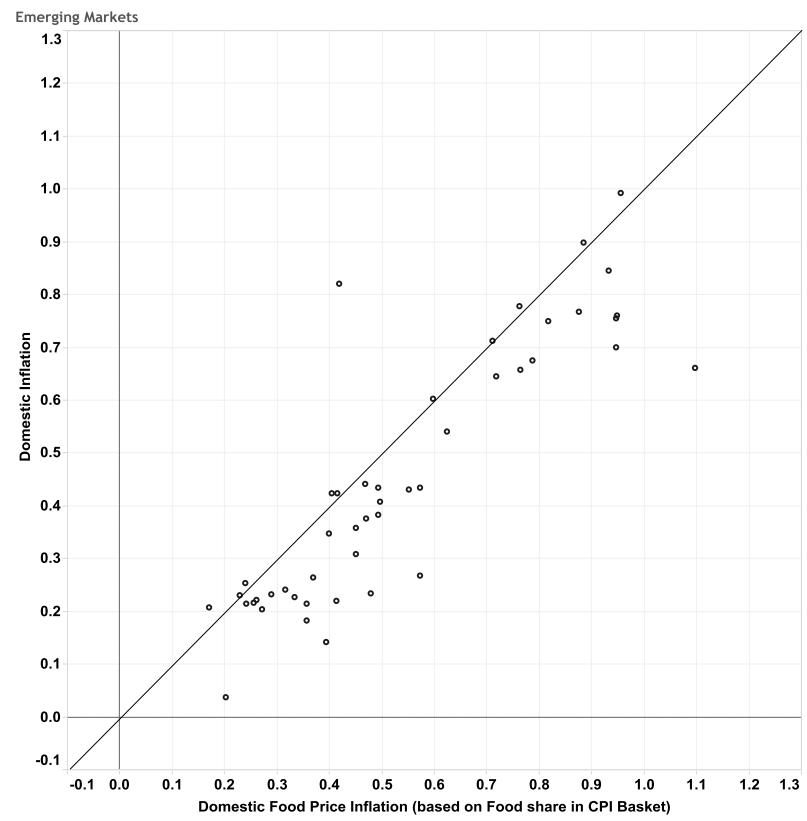

Source: authors' calculations using Haver Analytics.

Notes: The above chart takes the mean value of monthly inflation for the group of countries. Each dot represents the average monthly growth for a country's inflation between 2000 and 2013.

\section{Global Food Prices And Inflation: Results from Annual Data}

\subsection{Channels and estimation method}

This section outlines the channels through which global food price can affect inflation, which motivates the estimation that follows.

Let $P_{t}$ denote the headline consumer price index (CPI), which can be expressed as:

$$
P_{t}=P_{t}^{N} w_{t}^{\beta}
$$

where $w_{t}^{\beta}=P_{t}^{F} / P_{t}^{N}$ is the ratio of food to non-food price index; $\beta$ the share of food in the $\mathrm{CPI}$ basket; $\mathrm{F}$ and $N$ stand for food and non-food, respectively. Taking logs and first differences of Equation (1), headline inflation can then be written as:

$$
\pi_{t}=\pi_{t}^{N}+\beta \Delta \log w_{t}
$$

Equation (2) illustrates that overall inflation deviates from non-food (core) inflation by shocks to real food prices. This representation of headline inflation brings to the fore three channels of interest: (i) the scale of food price shocks; (ii) the food share weight; and (iii) the link to contemporary, New Keynesian, views on monetary policy in open economies which sees the objective of monetary policy as influencing 'sticky' prices to bring the economy as 
close as possible to the notional output and consumption path that would be followed if all prices were fully flexible (see, for example, Woodford, 2003).

In order to estimate the impact of global food prices on domestic inflation, we follow the method proposed by Jorda (2005) which consists of estimating impulse response functions directly from local projections. This approach has been advocated by, among others, Stock and Watson (2007) and Auerbach and Gorodnichenko (2013) as a flexible alternative that does not impose the dynamic restrictions embedded in vector autoregressive (autoregressive distributed lag) specifications.

Specifically, for each period $k$ the following equation is estimated on annual data:

$$
\pi_{i, t+k}=\alpha_{i}^{k}+\operatorname{Time}_{i t}^{k}+\sum_{j=1}^{l} \gamma_{j}^{k} \pi_{i, t-j-1}+\beta_{k} \delta_{i t} \pi_{i, t}^{i n t}+\varepsilon_{i, t}^{k}
$$

with $k=0, . .3$, and where $\pi$ represents domestic CPI inflation; $\pi_{i, t}^{i n t}$ is defined as the global food price inflation in year $t ; \delta_{i t}$, is the share of food in the domestic CPI in country $i$ at time $t, \alpha_{i}^{k}$ are country fixed effects; Time $e_{i t}^{k}$ denotes country-specific time trends; $\beta_{k}$ measures the impact of global food prices on domestic inflation for each future period $k$; and $\gamma_{j}^{k}$ captures the persistence of domestic CPI inflation. The inclusion of $\delta_{i t}$ allow us to permit heterogeneity across countries in terms of food imports while at the same time controlling for country-specific time trends in both inflation and food prices. ${ }^{6}$ Since fixed effects are included in the regression, the dynamic impact on inflation should be interpreted as compared to a baseline country-specific trend. In our baseline specification, the number of lags $(l)$ has been chosen to be equal to two, but the results are robust to the choice of lag length.

Impulse response functions (IRFs) are obtained by plotting the estimated $\beta_{k}$ with confidence bands for the estimated IRFs being computed using the standard deviations associated with the estimated coefficients. While the presence of a lagged dependent variable and country fixed effects may in principle bias the estimation of $\gamma_{j}^{k}$ and $\beta_{k}$ in small samples (Nickell, 1981), the length of the time dimension mitigates this concern. ${ }^{7}$

\subsection{Baseline results}

The results obtained by estimating the impact of global food price shocks on domestic inflation over the period 1960-2012 are presented in Table 1. The results show a positive and statistically significant effect on domestic inflation from global food price shocks. The effect is illustrated, along with the associated confidence bands (dotted lines), in Figure 5 for $\mathrm{k}=0$, $1,2,3$. It is evident that over the full sample period global food price shocks have long-lasting effects on domestic inflation. In particular, the estimates suggest that a 10 percent increase in global food price (weighted by the share of food imports in each country) typically increases domestic inflation by 0.35 percentage point in the very short term (i.e. in the year of the food

\footnotetext{
${ }^{6}$ See the Appendix for the sources and details on the construction of this variable.

${ }^{7}$ The finite sample bias is in the order of $1 / T$, where the average $T$ in the baseline sample is 43 .
} 
price shock), by about 0.4 percentage point in the medium term (i.e. 3 years after the shock), and with a peak effect of about 0.7 percentage point 1 year after the shock. Since many episodes of food price shocks involve increases of 50 percent or more, this is an economically significant effect as well.

Figure 5. The Impact of Food Price Shocks on Domestic (CPI) Inflation (percentage points)

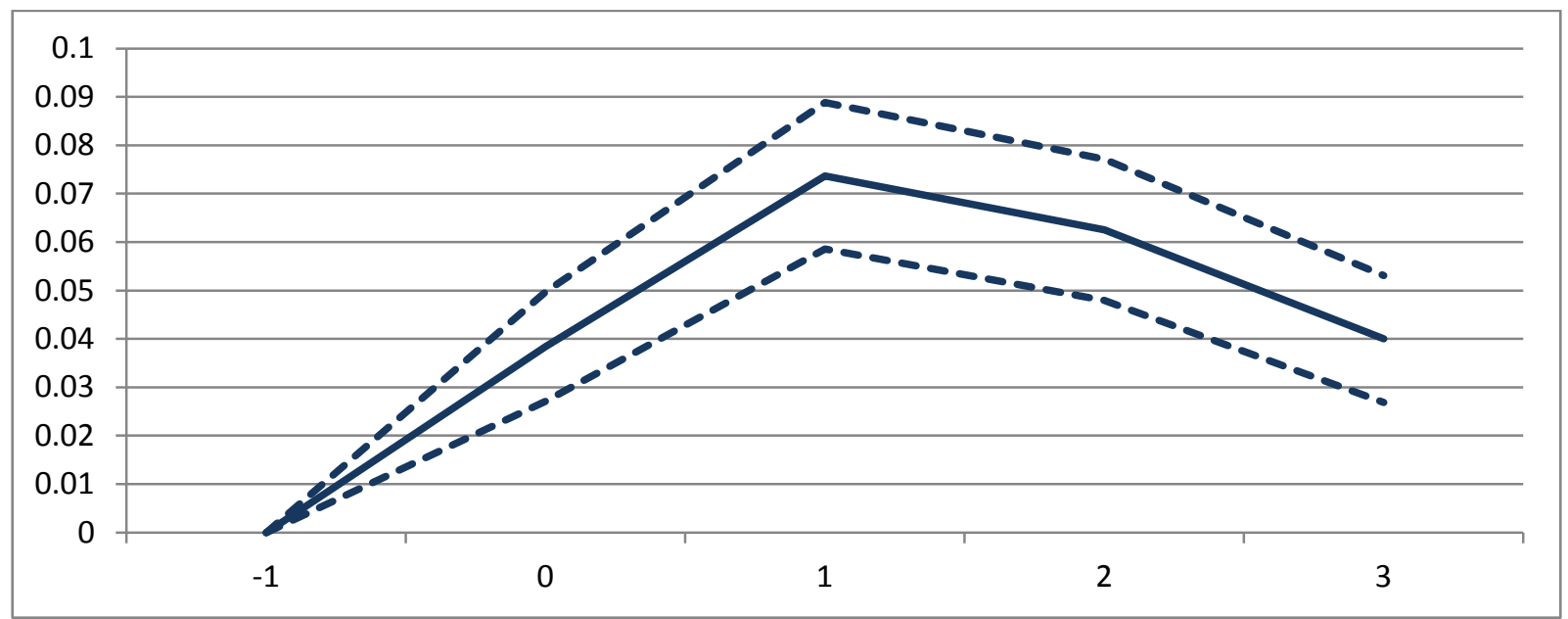

Note: the figure presents the impact of 1 percentage point change in world food price inflation on domestic (CPI) inflation. In this figure (and in figures 6 to 10), the solid line is the impulse response function (IRF) and the dotted lines indicates 90 percent confidence bands. $t=0$ denotes the year of the shock.

Table 1. Baseline Estimates

\begin{tabular}{|l|c|c|c|c|}
\hline & $\mathbf{k}=\mathbf{0}$ & $\mathbf{k}=\mathbf{1}$ & $\mathbf{k}=\mathbf{2}$ & $\mathbf{k = 3}$ \\
\hline$\delta_{i t} \pi_{i, t}^{\text {int }}$ & $\begin{array}{c}0.036 \\
(5.48)^{* * *}\end{array}$ & $\begin{array}{c}0.074 \\
(7.02)^{* * *}\end{array}$ & $\begin{array}{c}0.063 \\
(7.40)^{* * *}\end{array}$ & $\begin{array}{c}0.040 \\
(4.55)^{* * *}\end{array}$ \\
\hline$\pi_{i, t-1}$ & 0.607 & 0.386 & 0.289 & 0.187 \\
& $(4.23)^{* * *}$ & $(3.74)^{* * *}$ & $(3.68)^{* * *}$ & $(3.22)^{* * *}$ \\
\hline$\pi_{i, t-2}$ & 0.050 & 0.062 & 0.038 & 0.070 \\
& $(0.54)$ & $(0.83)$ & $(0.65)$ & $(1.27)$ \\
\hline & & & & 640 \\
\hline $\mathrm{N}$ & 706 & 684 & 662 & 0.55 \\
\hline $\mathrm{R}^{2}$ & 0.73 & 0.65 & 0.60 & $-10.720^{* * *}$ \\
\hline $\mathrm{IPS}$-statistics & $-17.700^{* * *}$ & $-13.745^{* * *}$ & $-12.407^{* * *}$ & \\
\hline
\end{tabular}

Note: T-statics based on clustered robust standard errors are reported in parentheses. $* * *$ denote significance at 1 percent level. IPS denotes the Im-Pesaran-Shin (IPS) test for unit root.

\subsection{Robustness checks}

The results presented in Equation (3) may be biased due to possible endogeneity. A first source of endogeneity is related to the inclusion of country fixed effects in the presence of a lagged dependent variable (Teulings and Zubanov, 2010). To address this problem, we 
have re-estimated Equation (1) without country fixed effects. The results reported in Panel A of Figure 6 suggest that this bias is negligible: the difference in the point estimates when compared with Figure 5 is small and not statistically significant.

Figure 6. The Impact of Food Price Shocks on Domestic (CPI) Inflation (percentage points), Robustness Checks.

\section{A. No country FE}

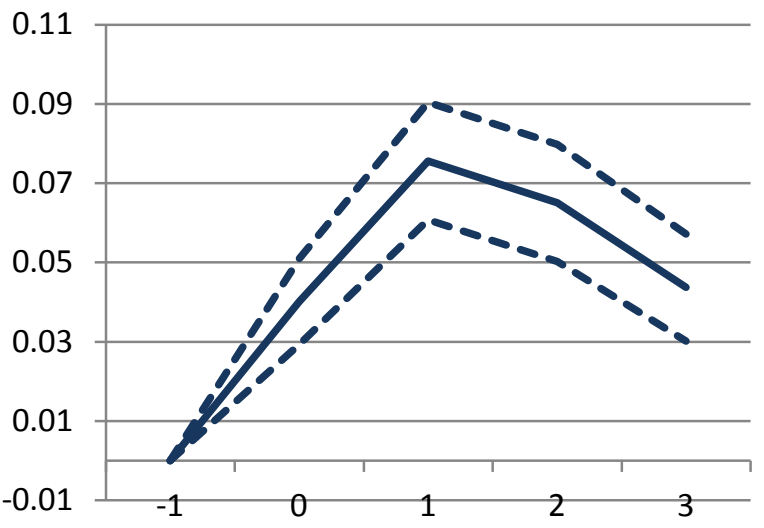

C. CPI inflation - food inflation

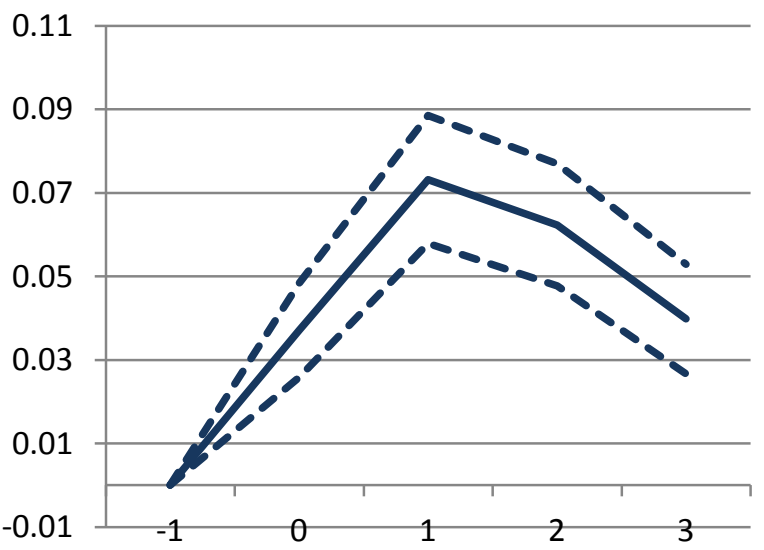

B. GMM

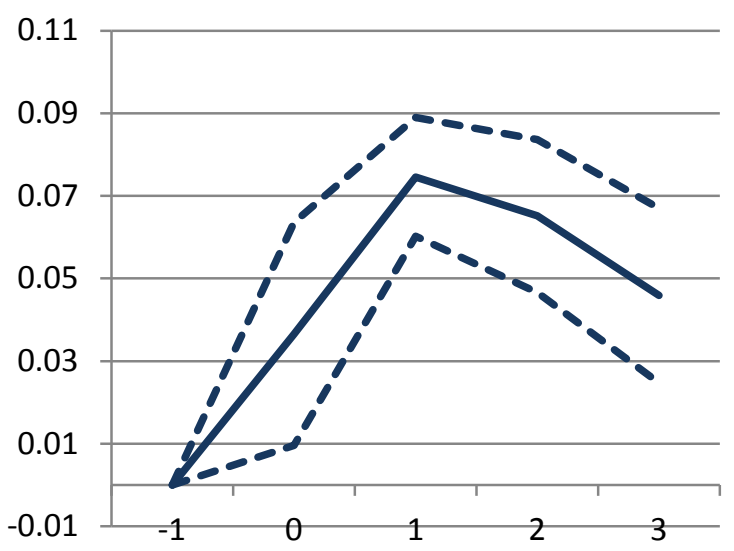

D. Panel VAR

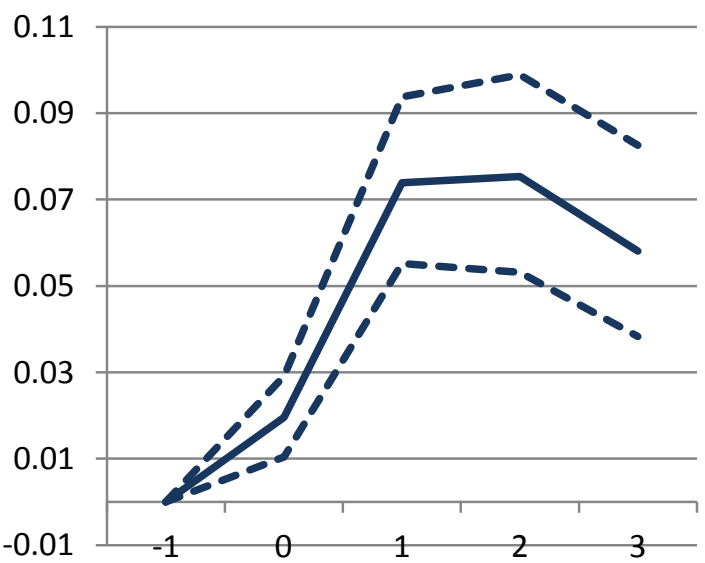

A second, and perhaps more relevant, source of endogeneity is reverse causality or the fact that unobserved factors not included in the estimation framework may jointly affect global food prices and domestic inflation. To address these issues, three alternative approaches are used. The first consists of estimating Equation (3) with a two-step generalized-method-of-moments system estimator, which uses up to four lags of domestic and global food price inflation as instruments for global food price inflation. The second 
approach tries to address endogeneity concerns by re-estimating Equation (3) using the difference between domestic price and global food inflation $\left(\pi_{i, t}-\pi_{i, t}^{i n t}\right)$ as the dependent variable. The third approach uses a panel-VAR approach to purge for possible lagged feedback effects from domestic inflation to global food price inflation. ${ }^{8}$ The estimates obtained using these three alternative specifications are similar to those obtained in the baseline (Figure 6B-D), confirming that the results are robust to these different checks.

\section{$3.4 \quad$ Sub-sample differences}

The estimates presented above for the full sample period may mask a change in the response of domestic inflation to global food prices over time. As noted earlier, for the United States, Blinder and Rudd found the response of domestic inflation to global food prices had declined since the early 1980s.

To test whether a similar finding holds for the entire sample of advanced economies, we re-estimate Equation 3 for two different sample periods: 1960-1982 and 1983-2012. The results presented in Figure 7 validate the hypothesis that impact of food prices on inflation has been muted in the latter period for the overall sample of advanced economies. In particular, while global food prices shocks have had large, statistically significant, and longlasting effects on domestic inflation until the early 1980s (Figure 7, Panel A), their effect has been much more modest and short-lived in the period 1983-2012 (Figure 7, Panel B).

The results are very similar when the share of food in the domestic CPI in each country $i$ is assumed to be constant at its time-average value over the entire sample. Comparing the two panels of Figure 8, it is clear that the impact is weaker in the latter period. This results suggests that change in the shares of food in the domestic CPI basket are not a key factor explaining the lower effect of global food price inflation on domestic inflation in the period 1983-2012.

Figure 9 shows the changes in the impact of food price inflation on overall inflation for the United Kingdom (Panel A) and the United States (Panel B). For both countries, the impact is much more muted in the latter period. ${ }^{9}$

\footnotetext{
${ }^{8}$ The panel-VAR approach assumes a Cholesky identification scheme in which global food price inflation is ordered first, followed by domestic inflation--this assumption implies that global food price inflation may have an effect on the contemporaneous domestic inflation, while domestic inflation has an effect on global food price inflation only with a lag. The lag length is chosen equal to 2 .

${ }^{9}$ The results are not sensitive to the exact cutoff date in the early 1980 s.
} 
Figure 7. The Impact of Food Price Shocks on Domestic (CPI) Inflation, 1960-82 vs.19832012 (percentage points)
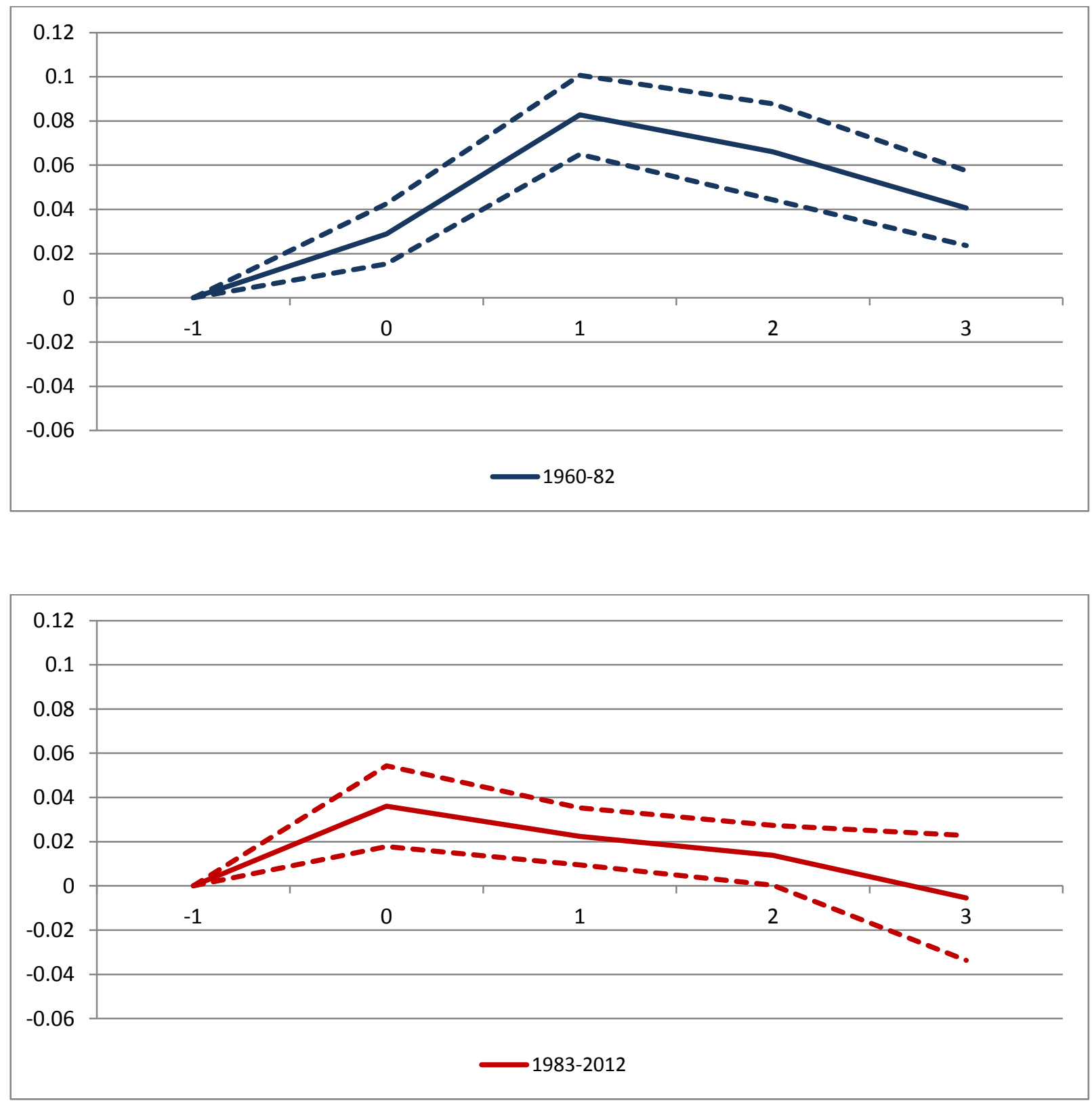
Figure 8. The Impact of Food Price Shocks on Domestic (CPI) Inflation, Assuming TimeInvariant Food Shares (percentage points)
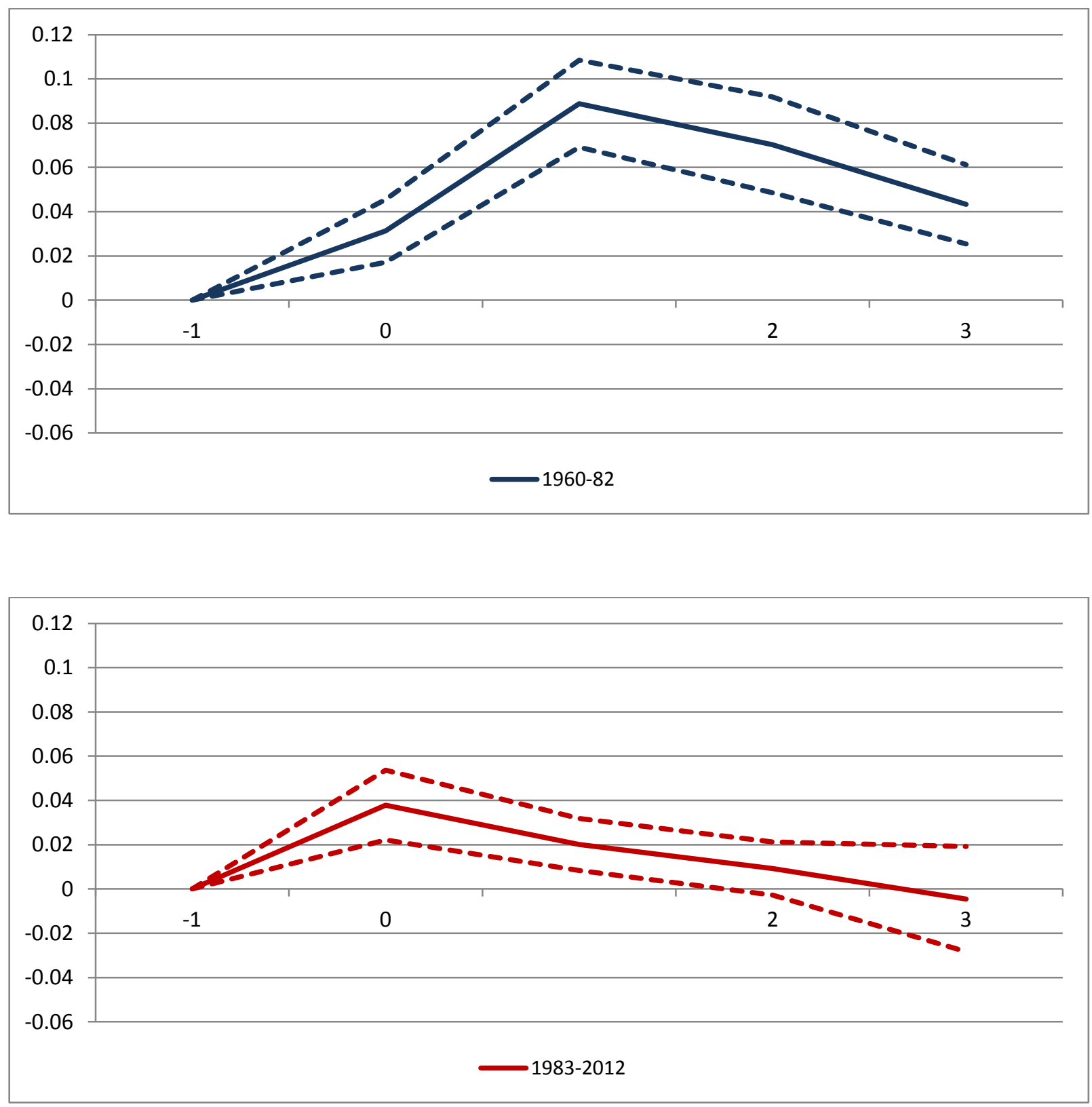
Figure 9. The Impact of Food Price Shocks on Domestic (CPI) Inflation, 1960-82 vs.19832012 for the UK and the US (percentage points)

Panel A. The United Kingdom

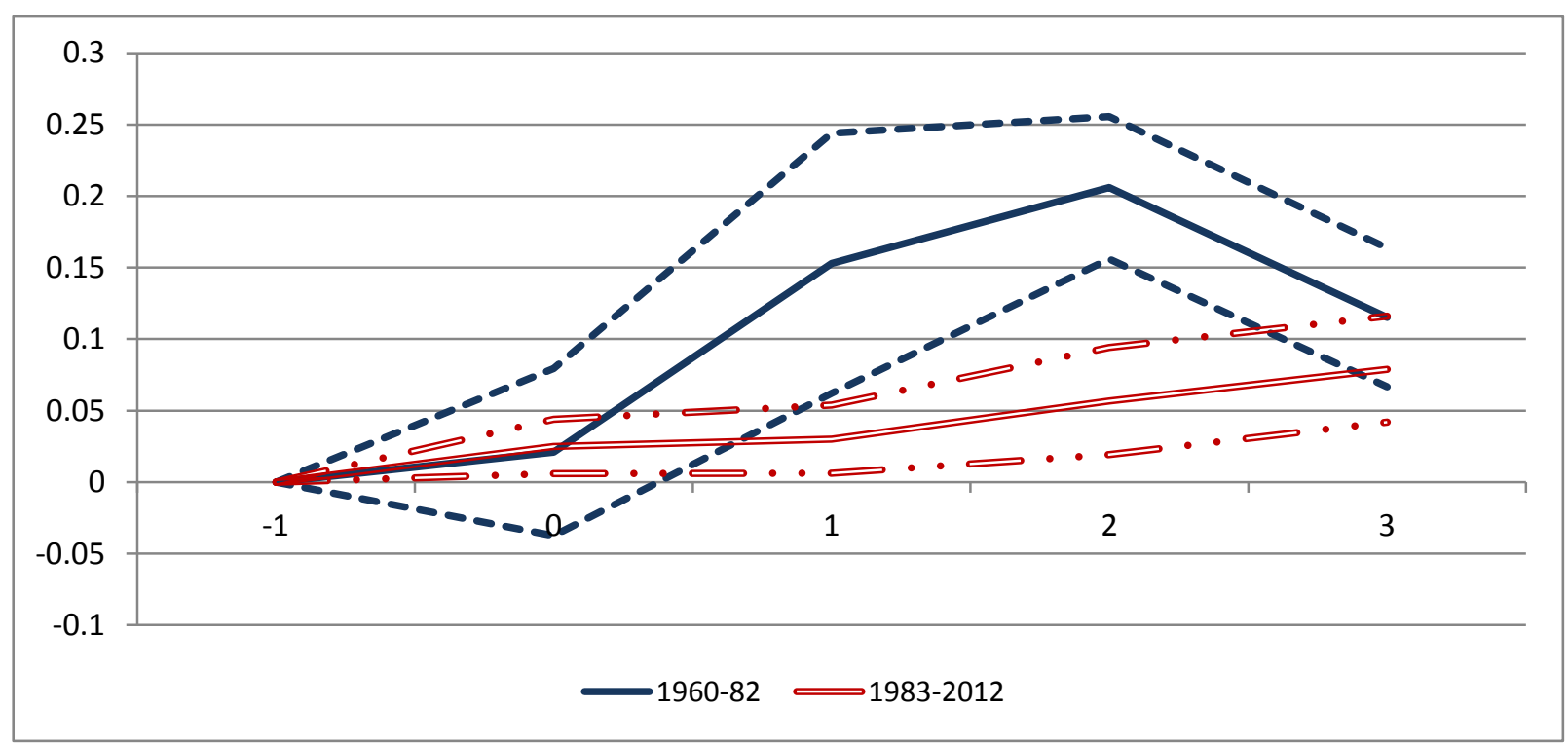

Panel B. The United States

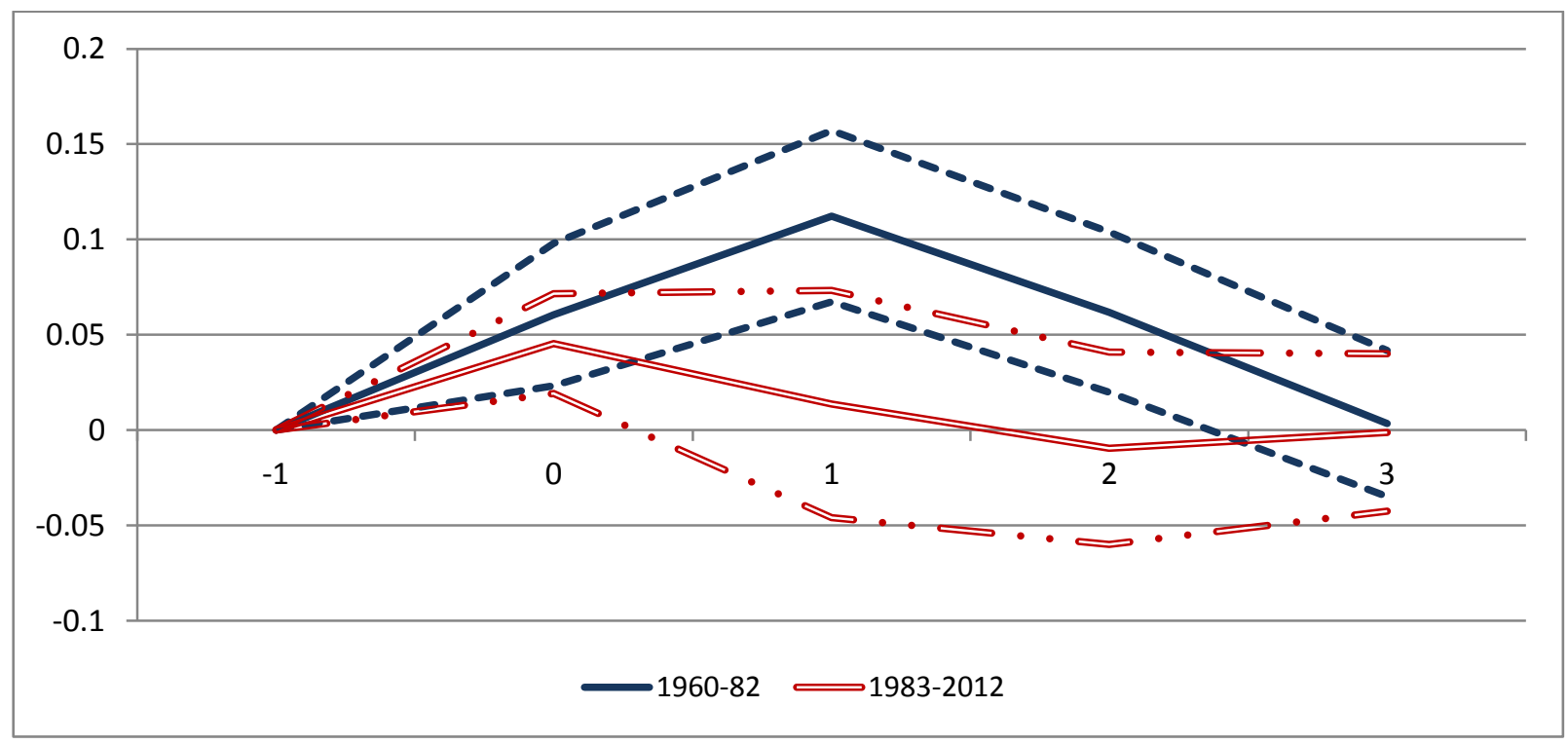




\subsection{Food shocks vs. monetary factors}

We conclude this section by checking if our results are robust of the inclusion of variables that can proxy for aggregate demand factors, which are often assumed to be the primary determinant of inflation. As a proxy for aggregate demand, we use excess money growth - defined as the difference between money growth and nominal GDP growth — as an additional independent variable in equation (3).

The results of this exercise are presented in Figure 10. The figure shows that while over the entire sample 1960-2012 both global food price and domestic excess money shocks have statistically significant and long-last effects on domestic inflation, the response to both shocks has changed over time. In particular, while the effect of global food prices shocks on domestic inflation dominates during the period 1960-82, the effect of excess money shocks on inflation is more persistent and more precisely estimated over the latter sample. These findings hold up to the various robustness checks discussed earlier. In sum, our results on the importance of global food shocks for inflation are robust to the inclusion of aggregate demand factors.

Figure 10. The Impact of Food Price and Excess Money Shocks on Domestic (CPI) Inflation (percentage points)

Food prices (1960-2012)

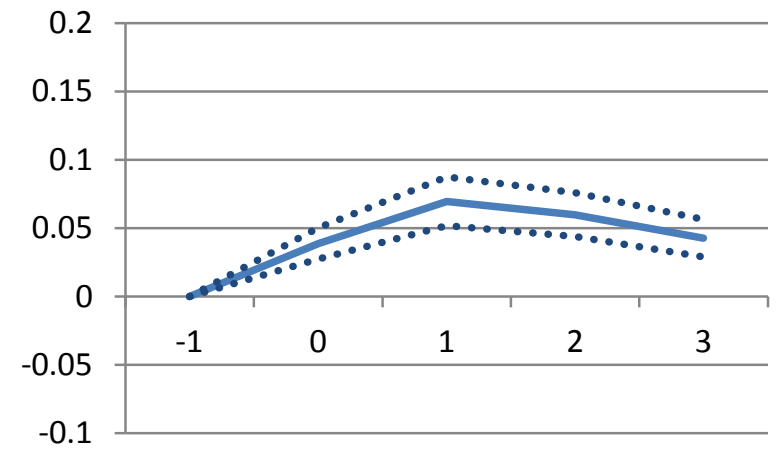

Excess money growth (1960-2012)

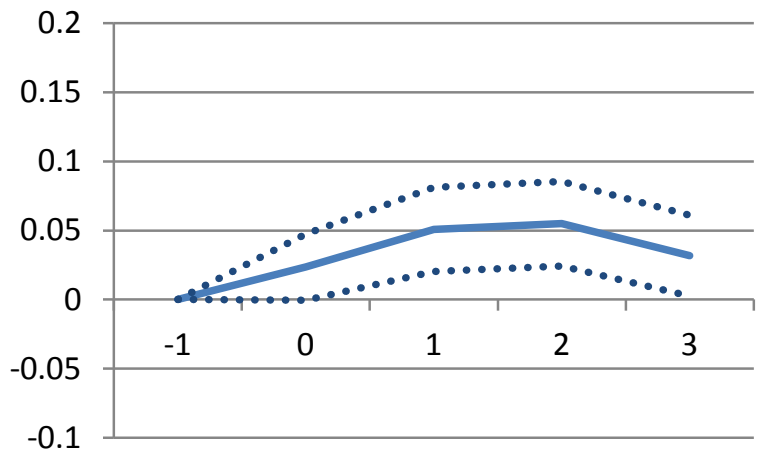


Food prices (1960-82)

Excess money growth (1960-82)

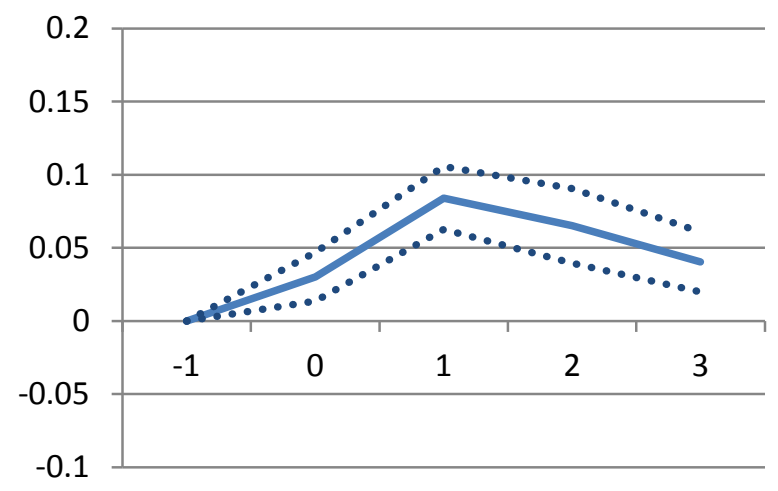

Food prices (1982-2012)

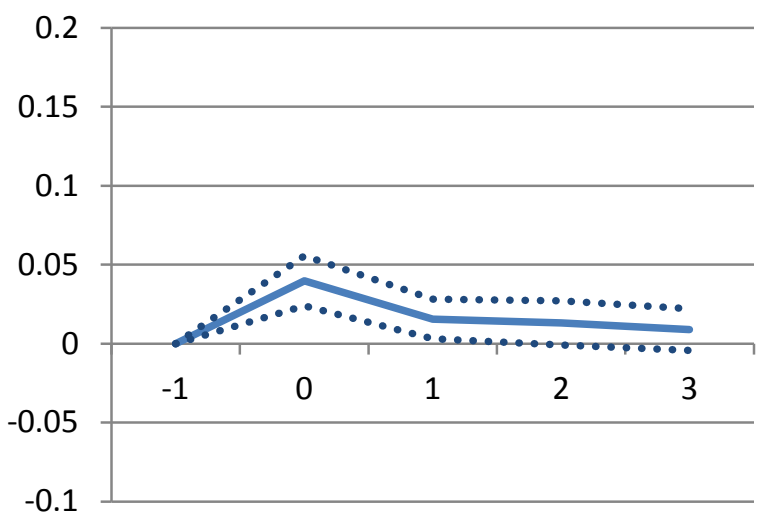

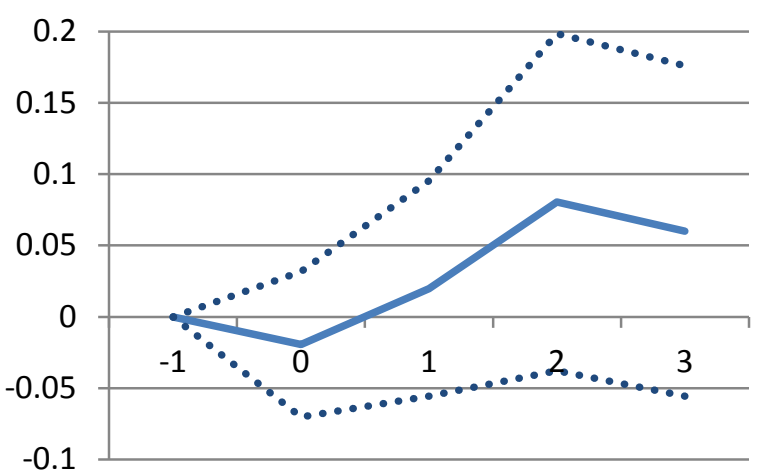

Excess money growth (1982-2012)

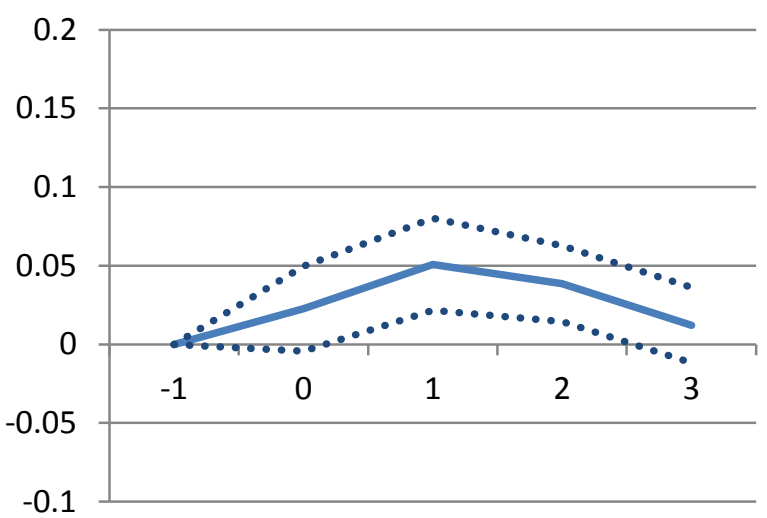

\subsection{Evidence for the 2000s from annual data}

We also provide some suggestive evidence from annual data on whether the impacts of the food price shocks of the 2000s have differed between advanced and emerging market economies by estimating Equation (3) separately for the two groups of countries. The results of this exercise are shown in Figure 11 and suggest that while the global food price shocks of the 2000s have had statistically significant short-term effects for both advanced and emerging market economies (Panel A), the effect on domestic inflation in emerging market economies (Panel C) has been slightly larger and more persistent than for advanced economies (Panel B). In the next section, we corroborate this finding using monthly data from the 2000 s using our second data set. 
Figure 11. The Impact of Food Prices on Domestic (CPI) Inflation, AEs vs. EMs, 1999-2012 (percentage points)

All countries

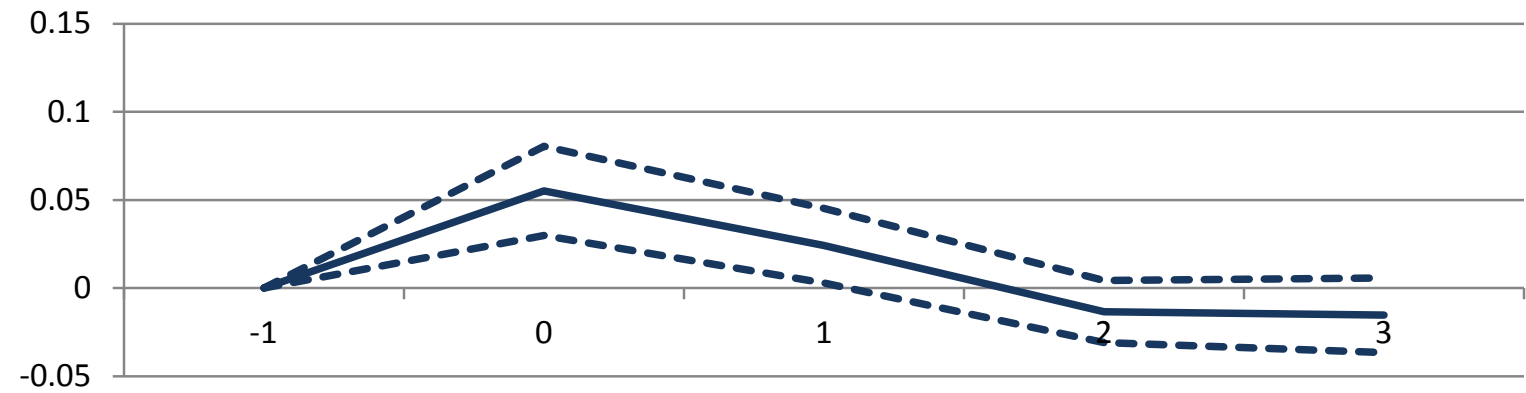

Advanced Economies

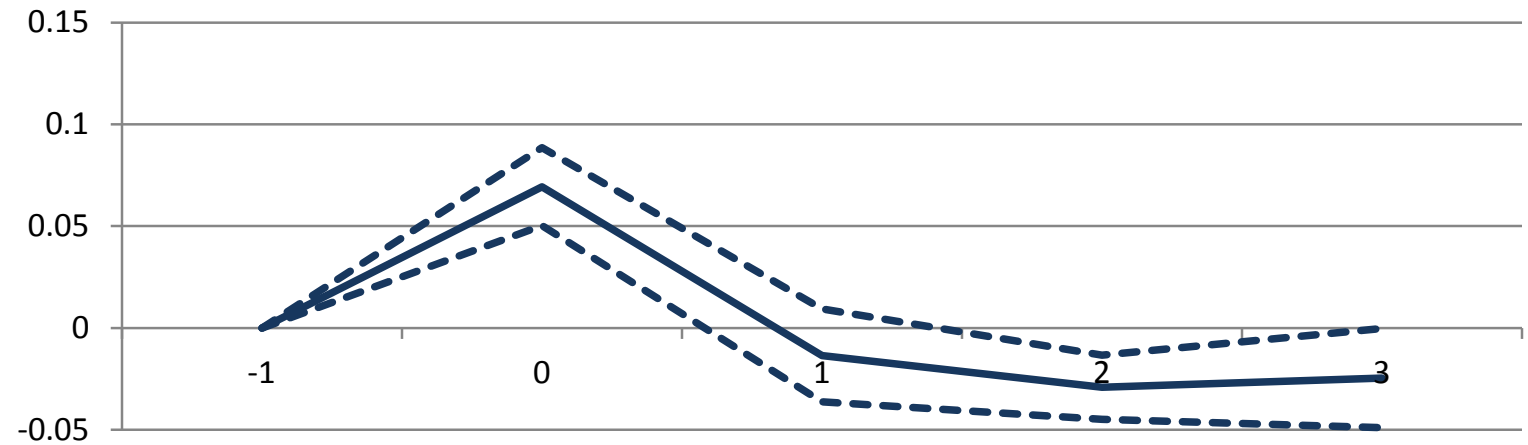

Emerging Economies

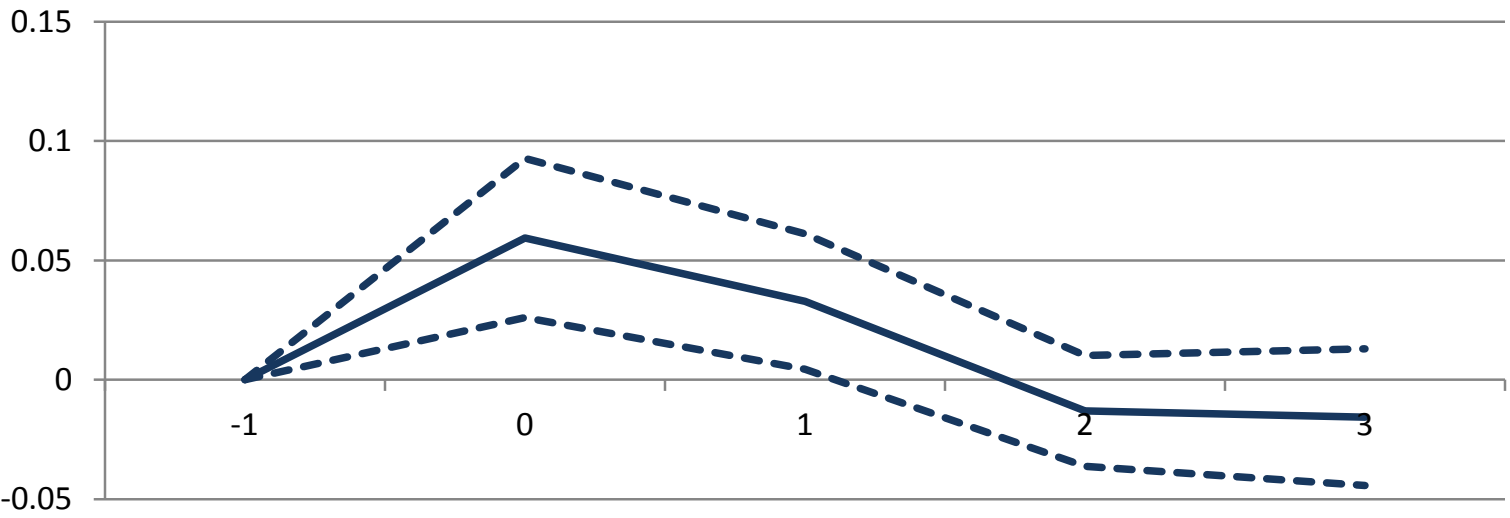

Note: the figure presents the impact of 1 percentage point change in world food price inflation on domestic (CPI) inflation. Solid line represents IRF; dotted lines indicated 90 percent confidence bands. $t=0$ denote the year of the shock. 


\section{EVIDENCE FROM MONTHLY DATA FOR THE 2000S}

In the previous section we provided evidence on how fluctuations in world food prices have contributed to overall inflation since the 1960s and how that impact has changed over time. The flare up in world food prices in the $2000 \mathrm{~s}$ - combined with the greater availability of higher frequency data for many more emerging economies - offers an opportunity to look more closely at differences between advanced and emerging economies and to study the channels of transmission from world food prices to domestic inflation. With these aims in mind, we first quantify the extent of pass-through from world food inflation to domestic food inflation and then the pass-though from domestic food inflation to overall inflation. We conclude this section by showing that inflation expectations are more anchored in advanced than in emerging economies, suggesting that this might be a channel for the smaller impact of world food inflation on overall inflation in advanced economies.

\subsection{Pass-through of world food inflation into domestic food inflation}

This section quantifies pass-through from world food prices to domestic prices based on a country-by-country regression of monthly domestic food price inflation on current and 12 lags of monthly international commodity price inflation, controlling for 12 lags of domestic food price inflation. In particular, the estimated equation is as follows:

$$
\pi_{t}^{d o m}=\alpha+\sum_{j=1}^{12} \beta_{j} \pi_{t-j}^{d o m}+\sum_{k=0}^{12} \gamma_{k} \pi_{t-k}^{i n t}+\varepsilon_{i, t}
$$

where $\pi_{t}^{d o m}$ denotes domestic food inflation in month $t$, and as before $\pi_{t}^{i n t}$ denotes world food inflation in month $t$. The pass-through coefficient is computed as the sum of the coefficients on international food price inflation $\left(\gamma_{k}\right)$ divided by 1 minus the sum of the coefficients on lagged domestic food inflation $\left(\beta_{j}\right)$.

Figure 12 shows the estimation results, which suggest that pass-through tends to be larger in emerging economies than in advanced economies. The median long-term passthrough of a 1 percent food price shock to domestic food prices is 0.18 percent in advanced economies and 0.34 percent in emerging economies.

A number of factors may be behind the incomplete pass-through. There is a significant local component in the production of food, including retail and distribution margins, excise taxes, and customs duties. Food subsidies may also limit the degree of passthrough. In addition, there is generally significant domestic production of food, making domestic agricultural and weather conditions more influential than global market developments. Moreover, world commodity price indices do not necessarily reflect the consumption bundle in any given country. The world index includes, for example, wheat, barley, and rice in proportion to their value in international trade, but domestic consumption patterns vary across countries. 
Figure 12. Pass-through from World Inflation to Domestic Inflation

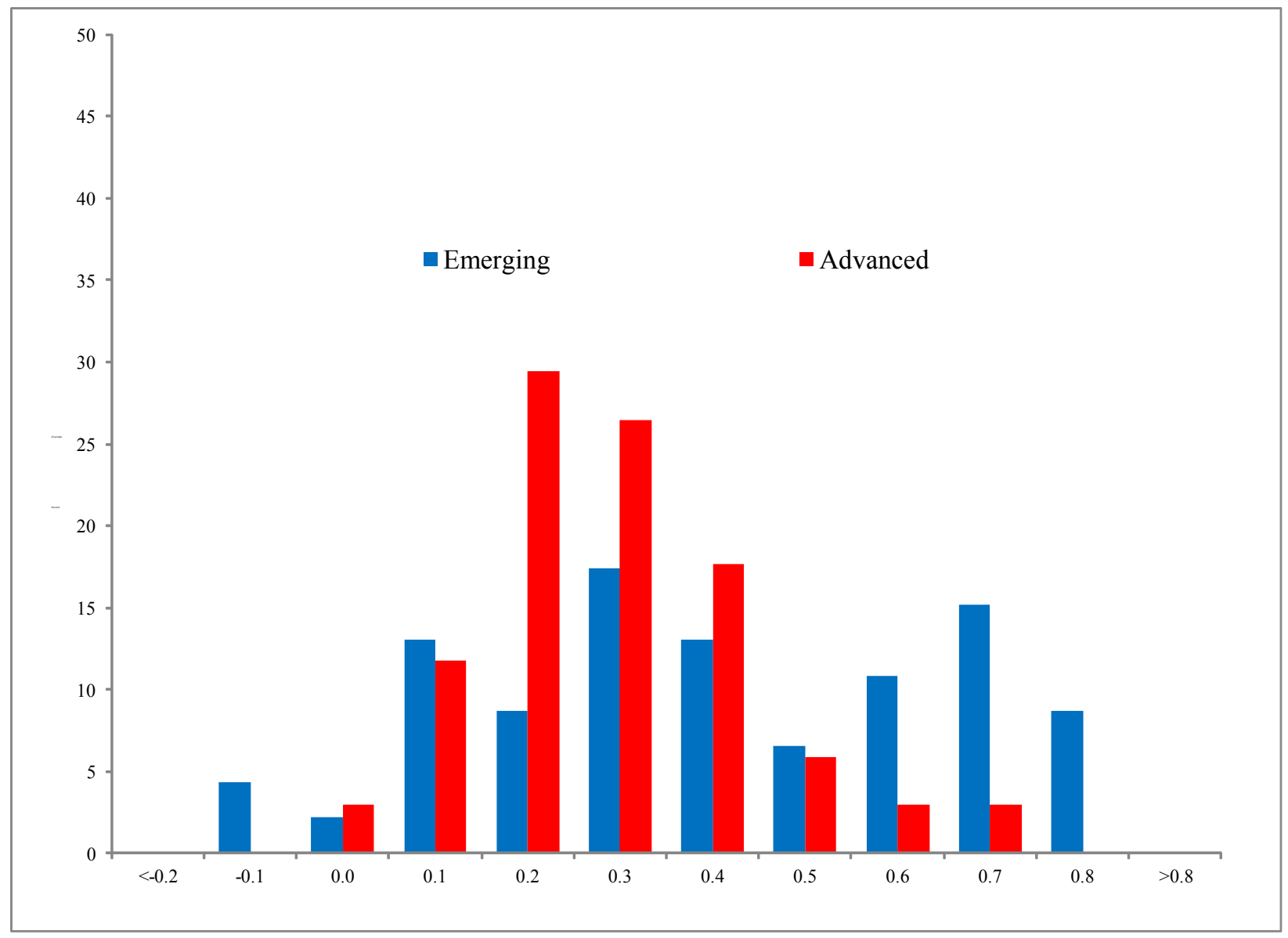

Note: The pass-through from international to domestic inflation is estimated using country-by-country bivariate regressions. The pass-through is calculated as the sum of coefficients on the current value and 12 lags of the international variable divided by 1 minus the sum of coefficients on the 12 lags of the domestic variable.

\subsection{Pass-through from domestic food inflation to overall inflation}

Two key factors are likely to influence the effect of domestic food prices on overall CPI inflation: the share of food in the consumption basket and the anchoring of inflation expectations. The higher the food share, the higher the likely direct effect on headline inflation. To the extent that food prices affect wage demands, higher pass-through to nonfood price inflation might be expected when the food share is higher. In countries with a poor track record of controlling inflation, food price shocks might also raise expectations of higher inflation in the future and might thereby raise pass-through when these expectations are reflected in prices.

The share of food in the CPI consumption basket is typically higher in emerging and developing economies than in advanced economies, as shown in Figure 13. For advanced economies in our sample, the median food share is 17 percent, whereas in emerging 
economies, the median is 31 percent. The higher food share implies that global food price shocks will have a strong direct effect on overall inflation in these economies. These direct effects are shown in Figure 14. In 2008, food prices contributed about 5 percentage points to overall inflation in emerging economies on average, but only about 1 percentage point to advanced economy inflation. Since then, the contribution exceeded 2 percentage points for emerging developing economies and about half a percentage point for advanced economies. These averages also mask significant variations among economies - in some, food prices raised headline inflation by about 10 percentage points in 2008 and 5 percentage points in the more recent period.

Finally, another reason why international food price shocks are likely to have a smaller impact on domestic inflation in advanced economies than in emerging economies is that measures of international food prices are generally composed of estimates of relatively unprocessed food commodities. In more developed countries, however, most food consumed is highly processed, so that the importance of raw materials in the final product (which is what enters the domestic CPI) is quite small. This is similar to, but somewhat distinct from, the argument that there is a smaller share of food in the CPI basket in advanced economies.

Figure 13. Share of Food in the Consumption Basket

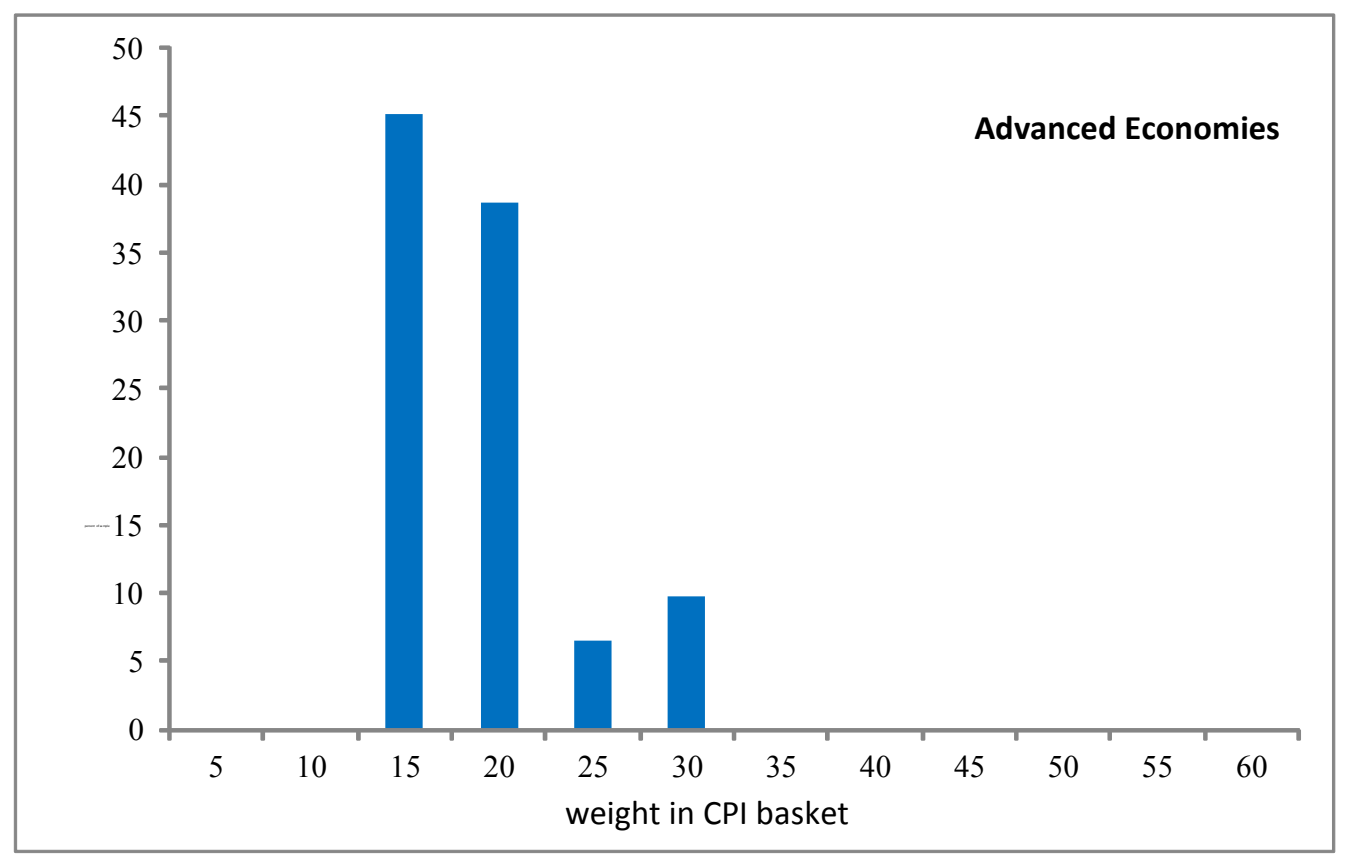




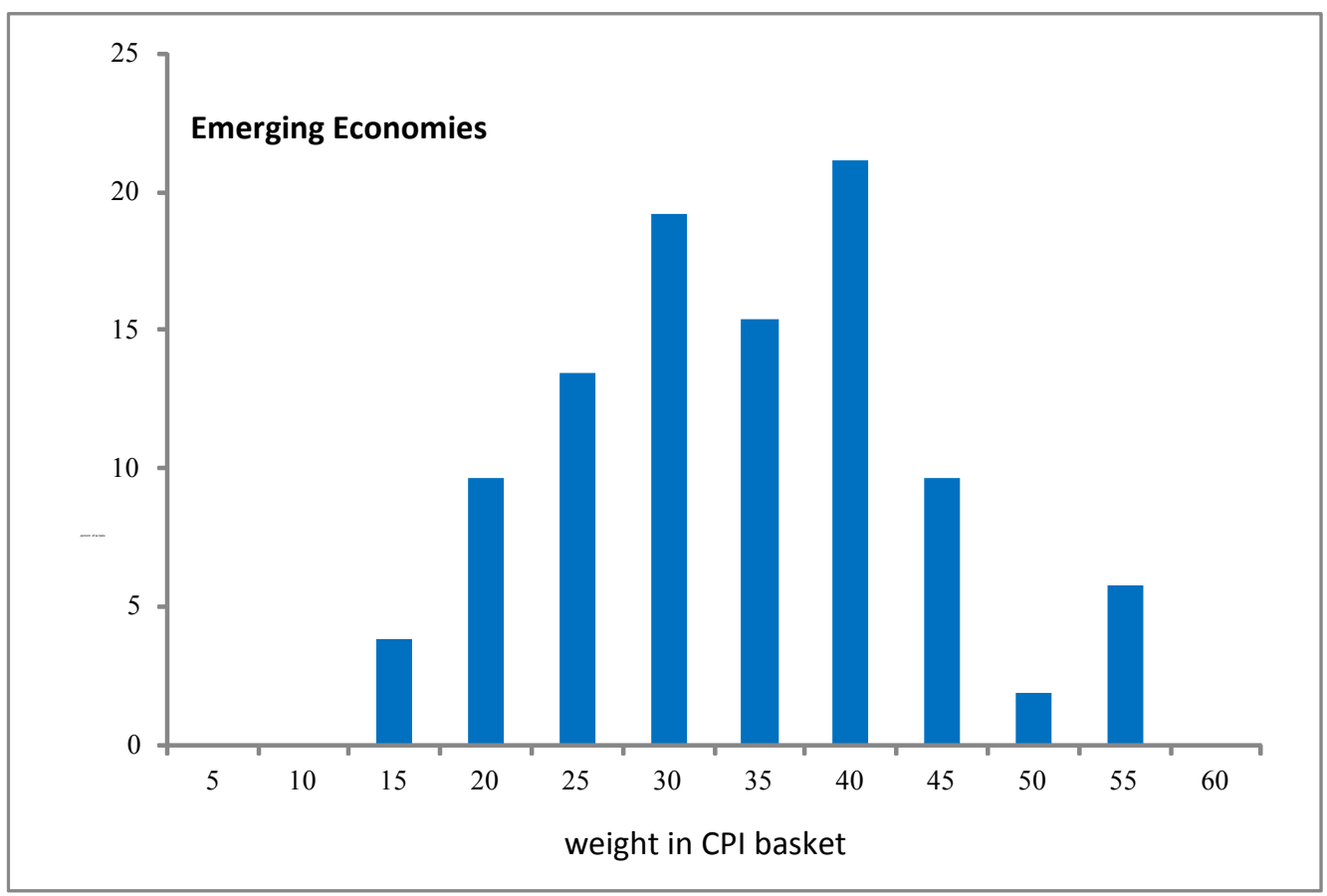

Note: The above chart provides a frequency distribution of the share of food in a country's CPI basket.

Figure 14. Contribution of Food to Overall Inflation

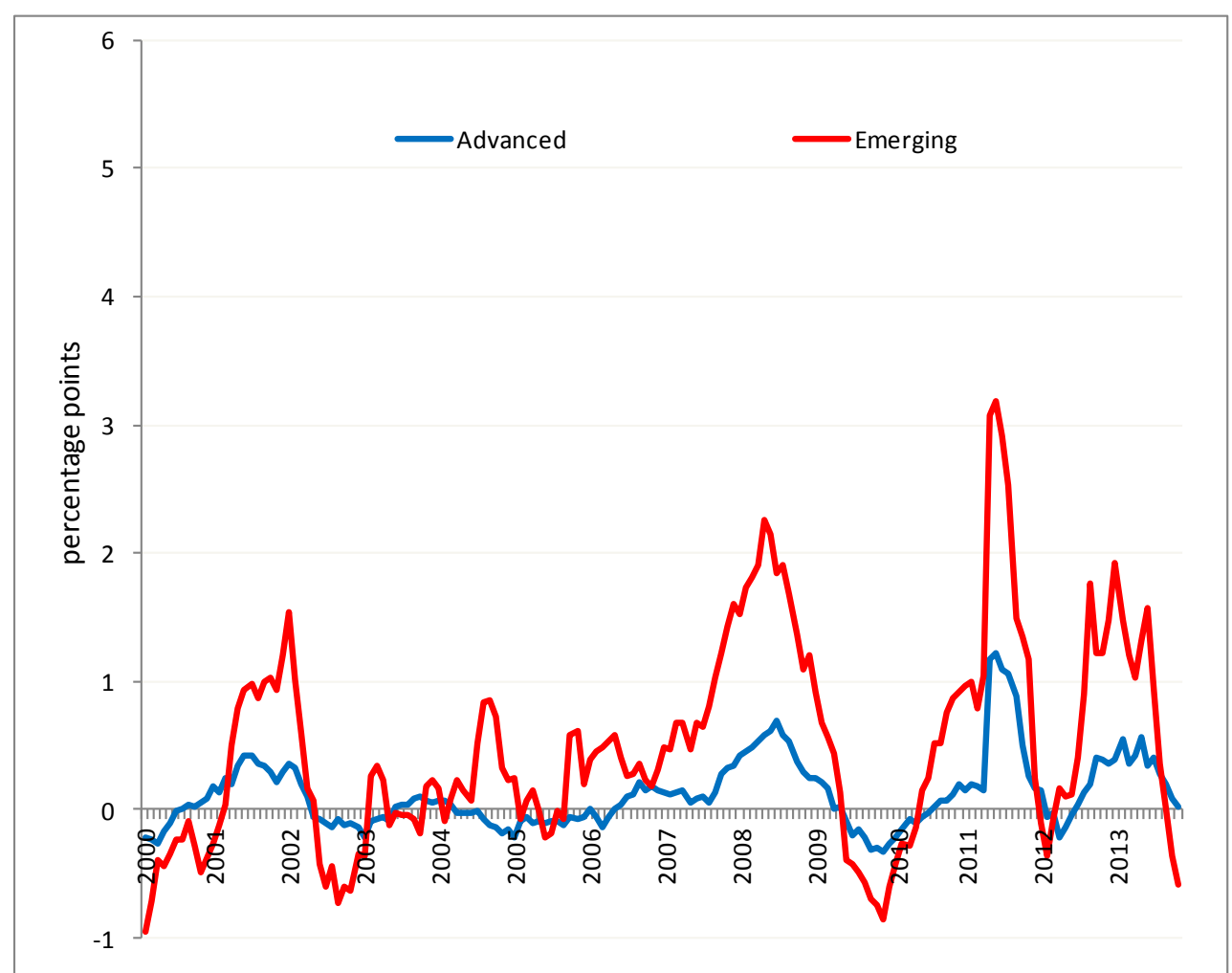

Source: authors' calculations.

Note: The above chart plots the net contribution of food price shock to overall CPI. 


\subsection{The role of inflation expectations}

In addition to the direct impact from differences in food shares, the overall effect of a food price shock on inflation is also likely to depend on how well inflation expectations are anchored. If monetary policy credibility is low, then medium-term inflation expectations are likely to be revised upward in response to incoming inflation news. By contrast, if the private sector believes that the central bank will stabilize inflation, then medium-term inflation expectations should respond little to incoming inflation news, thus requiring smaller adjustments in monetary policy.

The extent to which inflation expectations are anchored is estimated using the response of medium-term inflation expectations to an unexpected increase in inflation in the current period. In particular, we estimate the average response of expectations of future inflation to an unexpected 1 standard deviation increase in inflation in the current year. The inflation expectation data are based on surveys of professional forecasters conducted in 20 advanced and 18 emerging and developing economies over the past two decades, and the statistical approach is based on that of Levin, Natalucci, and Piger (2004). We also explore how the response differs between advanced and emerging economies and across different monetary policy regimes.

The change in future inflation expectations is the dependent variable on the left side of the equation, and the explanatory variable on the right side is the unexpected change in current-year inflation, defined as the revision of expectations for inflation in year $t$ made between spring and fall of year $t$. Thus, the equation estimated is

$$
\Delta E_{i t} \pi_{i, t+N}=\alpha+\beta \Delta E_{i t} \pi_{i t}+\mu_{i}+\lambda_{t}+v_{i, t}
$$

where the subscript $i$ denotes the $i$ th country, the subscript $t$ denotes the $t$ th year, and $\Delta E_{i t} \pi_{i, t+N}$ denotes the revision of expectations for inflation in year $t+N$. The approach includes a full set of country dummies $\left(\mu_{i}\right)$ and a full set of time dummies $\left(\lambda_{t}\right)$ to take account of global shocks. The results are similar without controlling for global shocks, suggesting that inflation expectations are anchored roughly equally following global and domestic inflation shocks. The data on inflation expectations come from Consensus Economics and are based on surveys of professional forecasters published twice yearly in the spring (March/April) and fall (September/October) from 1990 to 2013 (see Table A.4 for the list of countries included in this part of the analysis).

A key result is that expectations are generally less well anchored in emerging and developing economies than in advanced economies. On average, in emerging and developing economies, a 1 standard deviation shock to current-year inflation expectations, equal to 1.8 percentage points, has a substantial effect on medium-term inflation expectations. As Panel A of Figure 15 illustrates, even as far as five years into the future, inflation is still expected to rise by 0.3 percentage points in response to such a shock. By contrast, in advanced economies, a 1 standard deviation shock to current-year inflation expectations, equal to 0.6 percentage point, has a negligible effect on medium-term inflation expectations $(0.04$ percentage point), suggesting a higher degree of policy credibility. 
Figure 15. Response of Inflation Expectations to Inflation Surprises

\section{Panel A: Advanced vs. Emerging Economies}

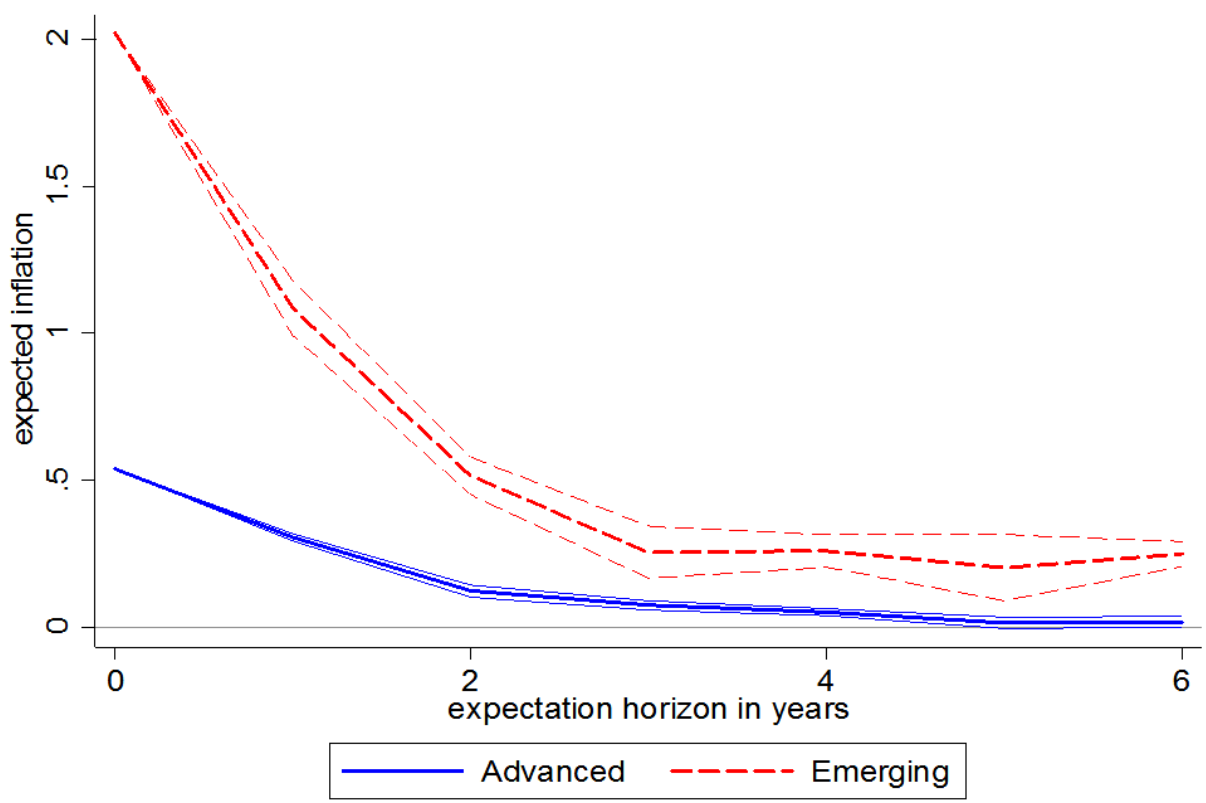

Panel B: Emerging Economies with and without Inflation Targeting

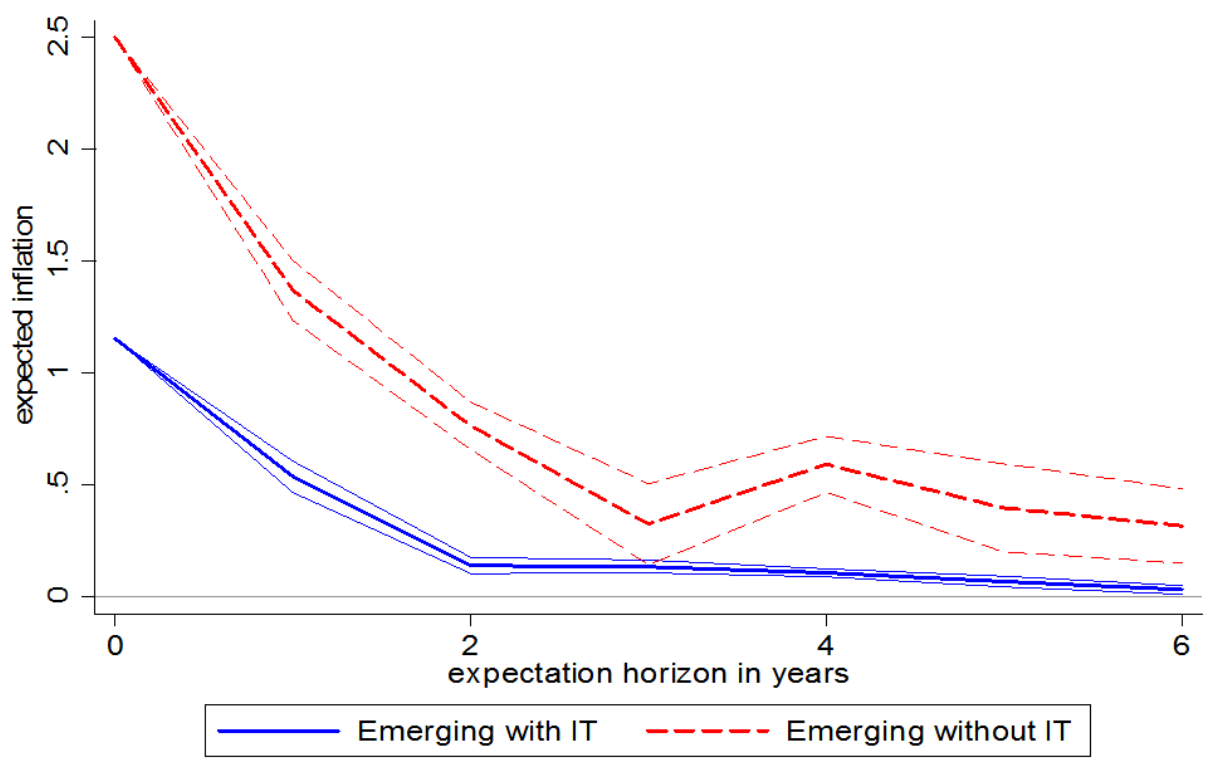

Note: This figure shows expectations of inflation in the current year and one to five years ahead as percentage point responses to a 1 standard deviation shock to current-year inflation and the estimated effect of a 1 standard deviation unexpected change in domestic consumer price index inflation based on private sector inflation expectations surveyed by Consensus Economics, 1990-2014 spring and fall vintages. Unexpected change occurs in year $\mathrm{t}=0$. 
These results imply that medium-term expectations change 2.5 times more in emerging and developing economies than in advanced economies following a given inflation surprise - $(0.3 / 1.8)$ divided by $(0.04 / 0.6)$. Additional analysis suggests that the response of medium-term expectations is similar for positive and negative inflation surprises. In particular, we allow positive and negative inflation surprises to have different effects by estimating an augmented equation,

$$
\Delta E_{i t} \pi_{i, t+N}=\alpha+\beta \Delta E_{i t} \pi_{i t}+\gamma \Delta \text { Positive } i t+\mu_{i}+\lambda_{t}+v_{i, t},
$$

where the term $\Delta$ Positive $_{i t}$ denotes a positive inflation surprise. This yields an estimate of the coefficient $\gamma$ that is not statistically different from zero.

Not all emerging economies, however, have weakly anchored inflation expectations. Inflation expectations appear to be well anchored in emerging economies in which the central bank has an explicit inflation target, as shown in Panel B of Figure 15. In particular, in emerging economies that use an inflation-targeting framework, expectations of inflation two or more years in the future respond little to current-year inflation surprises. ${ }^{10}$ In these economies, after a 1 standard deviation shock equal to 1.3 percentage points, inflation expectations five years out rise by only 0.07 percentage point, which is statistically indistinguishable from the response estimated for advanced economies. By contrast, where there is no inflation-targeting framework, inflation expectations as far as five years out rise by 0.5 percentage point following a 1 standard deviation surprise in current-year inflation. ${ }^{11}$ The benefits of inflation targeting may reflect the general quality of domestic monetary management and institutions in economies that adopt such a framework.

\section{Conclusions}

This paper provides a broad brush look at the impact of fluctuations in global food prices on domestic inflation in a large group of countries. For advanced economies, we find that these fluctuations have played a significant role over the period from 1960 to the present. Our baseline estimate is that a 10 percent increase in global food inflation has a peak impact of raising domestic inflation in advanced economies by about $1 / 2$ percentage points after a year. We find, however, that the impact has declined over time and become less persistent. Over the period since the 1980 s, the impact fell to about $1 / 4$ percentage points and it occurred

\footnotetext{
${ }^{10}$ To classify countries, we use the definition of the inflation-targeting framework in Roger (2010), which includes four main elements: (1) an explicit central bank mandate to pursue price stability as the primary objective of monetary policy and a high degree of operational autonomy; (2) explicit quantitative targets for inflation; (3) central bank accountability for performance in achieving the inflation objective, mainly through high-transparency requirements for policy strategy and implementation; and (4) a policy approach based on a forward-looking assessment of inflation pressures, taking into account a wide array of information.

${ }^{11}$ Most of these economies have pegged exchange rates, which reduces their ability to respond to shocks to domestic inflation. However, additional analysis suggests that inflation expectations are just as weakly anchored in emerging economies that do not have an inflation-targeting framework and have floating exchange rates (according to the de facto classification compiled by Ilzetzki, Reinhart, and Rogoff, 2008). Thus, the association between inflation targeting and the anchoring of expectations is not driven by the exchange rate regime.
} 
in the year of the increase of global food prices; after a year, there was essentially no impact on domestic inflation. As Blinder and Rudd (2008) note, this diminished role may be due to (i) the absence of significant food shocks in the 1980s and the 1990s; (ii) the declining share of food in the consumption basket; (iii) other changes in the structure of economies such as greater wage flexibility, which prevents a wage-price spiral; (iv) and, perhaps most important, an increase in the credibility of monetary policy so that an unexpected increase in inflation - due to events such as food price shocks - does not lead to a change in inflation expectations.

The increase in global food prices since the 2000s - which included three spikes in these prices - provides somewhat of a controlled experiment to discriminate among these channels. Using a second data set consisting of monthly CPI information for a large group of advanced and emerging economies, we find that these more recent global food price shocks had a much bigger impact on emerging than on advanced economies. This larger impact could reflect the larger share of food in the consumption baskets in emerging economies on average than in advanced economies. We also provide evidence that inflation expectations are more anchored in advanced than in emerging economies, which can also contribute to a smaller impact in advanced economies from a sudden burst in inflation due to global food price shocks. 


\section{Appendix}

\section{Sources and Definitions of Variables}

\begin{tabular}{|c|c|c|c|}
\hline Definition & Source & Note & Transformation \\
\hline Consumer Price Index & Haver Analytics & & $\begin{array}{l}\text { Use } y \text {-o-y growth rate to } \\
\text { produce yearly CPI inflation }\end{array}$ \\
\hline Nominal GDP & WEO and IFS, IMF. & $\begin{array}{l}\text { Available in local currency, } \\
\text { US\$, or GDP (constant prices } \\
\text { US\$) }\end{array}$ & $\begin{array}{l}\text { Use y-o-y growth rate of the } \\
\text { log of nominal GDP to } \\
\text { produce yearly nominal GDP }\end{array}$ \\
\hline M2 & IFTSTSUB & Measured in local currencies & $\begin{array}{l}\text { Use } y-0-y \text { growth rate of the } \\
\text { log of } M 2 \text { to produce yearly } \\
\text { M2 growth rate }\end{array}$ \\
\hline World Food Price & IMF Primary Commodity Prices & $\begin{array}{l}\text { Food Price Index, } 2005=100 \text {, } \\
\text { includes Cereal, Vegetable } \\
\text { Oils, Meat, Seafood, Sugar, } \\
\text { Bananas, and Oranges Price } \\
\text { Indices }\end{array}$ & $\begin{array}{l}\text { Use y-o-y growth rate to } \\
\text { produce yearly world food } \\
\text { price inflation }\end{array}$ \\
\hline Inflation Expectation & Consensus Economic Forecasts & & \\
\hline Advanced and Emerging dummy & IMF & $\begin{array}{l}\text { Follow the IMF country } \\
\text { classification }\end{array}$ & \\
\hline CPI Food basket share & country statistical sources and Haver Analytics & & $\begin{array}{l}\text { CPI Food basket share * world } \\
\text { food price }\end{array}$ \\
\hline Food Import Share (\% of total impor & $\begin{array}{l}\text { World Bank staff estimates from the Comtrade } \\
\text { database maintained by the United Nations } \\
\text { Statistics Division }\end{array}$ & $\begin{array}{l}\text { The classification of } \\
\text { commodity groups is based } \\
\text { on the Standard International } \\
\text { Trade Classification (SITC) } \\
\text { revision } 3 .\end{array}$ & $\begin{array}{l}\text { Country Food imports (\% of } \\
\text { merchandise imports) * world } \\
\text { food price }\end{array}$ \\
\hline
\end{tabular}

Table A.1: Summary Statistics for World Sample

\begin{tabular}{|c|c|c|c|c|}
\hline $\begin{array}{l}\text { Domestic } \\
\text { Inflation }\end{array}$ & $\begin{array}{c}\text { Food Inflation } \\
\text { (measured by share of } \\
\text { food in domestic CPI } \\
\text { basket) }\end{array}$ & $\begin{array}{c}\text { Average } \\
\text { Food Weight } \\
\text { in CPI Basket }\end{array}$ & M2 Growth & $\begin{array}{l}\text { GDP Growth } \\
\text { (nominal local } \\
\text { currencies) }\end{array}$ \\
\hline
\end{tabular}

World

\begin{tabular}{|c|c|c|c|c|c|}
\hline $\mathrm{N}$ & 1445 & 1458 & 493 & 1340 & 1457 \\
\hline Mean & 17.1 & 3.2 & 24.3 & 16.2 & 14.0 \\
\hline \multicolumn{6}{|c|}{ Advanced Economies } \\
\hline $\mathrm{N}$ & 795 & 837 & 336 & 676 & 795 \\
\hline Mean & 4.7 & 2.7 & 19.2 & 9.2 & 7.5 \\
\hline \multicolumn{6}{|c|}{ Emerging Markets } \\
\hline $\mathrm{N}$ & 710 & 715 & 202 & 724 & 725 \\
\hline Mean & 30.2 & 3.7 & 32.4 & 22.2 & 20.6 \\
\hline
\end{tabular}


Table A.2: Summary Statistics by Country

\begin{tabular}{|c|c|c|c|c|c|c|c|c|c|c|}
\hline & $\begin{array}{c}\text { Domestic } \\
\text { Inflation }\end{array}$ & $\begin{array}{c}\text { Food Inflation } \\
\text { (measured by } \\
\text { share of Food in } \\
\text { Domestic CPI } \\
\text { basket) }\end{array}$ & M2 Growth & $\begin{array}{l}\text { GDP Growth } \\
\text { (nominal local } \\
\text { currencies) }\end{array}$ & $\begin{array}{l}\text { Average } \\
\text { Food } \\
\text { Weight in } \\
\text { CPI Basket }\end{array}$ & $\begin{array}{c}\text { Domestic } \\
\text { Inflation }\end{array}$ & $\begin{array}{c}\text { Food Inflation } \\
\text { (measured by } \\
\text { share of Food in } \\
\text { Domestic CPI } \\
\text { basket) }\end{array}$ & M2 Growth & $\begin{array}{l}\text { GDP Growth } \\
\text { (nominal local } \\
\text { currencies) }\end{array}$ & $\mathrm{N}$ \\
\hline & & & & & & & Standard De & viation & & \\
\hline \multicolumn{11}{|c|}{ Advanced Economies (AE's) } \\
\hline Australia & 5.2 & 3.3 & 10.2 & 8.5 & 16.5 & 3.9 & 15.1 & 4.9 & 3.8 & 54 \\
\hline Austria & 3.5 & 3.5 & 5.3 & 6.1 & 12.1 & 2.0 & 15.0 & 5.2 & 3.1 & 54 \\
\hline Canada & 4.8 & 3.1 & 8.6 & 7.8 & 17.5 & 3.3 & 16.6 & 4.8 & 3.9 & 39 \\
\hline Denmark & 2.1 & 2.6 & 4.9 & 3.5 & 12.6 & 0.5 & 10.8 & 6.2 & 2.5 & 22 \\
\hline France & 4.5 & 3.0 & 6.4 & 7.2 & 16.4 & 3.8 & 15.1 & 4.0 & 4.4 & 54 \\
\hline Germany & 2.3 & 3.0 & 2.3 & 4.5 & 11.8 & 4.1 & 15.4 & 2.5 & 2.9 & 53 \\
\hline Iceland & 5.6 & 4.0 & 13.2 & 7.6 & 15.1 & 3.0 & 10.1 & 20.7 & 3.9 & 16 \\
\hline Italy & 9.6 & -0.8 & 9.7 & 11.8 & 18.6 & 5.9 & 11.4 & 6.8 & 6.0 & 25 \\
\hline Japan & 3.4 & 2.8 & 8.6 & 6.4 & 31.6 & 4.4 & 15.3 & 6.4 & 6.7 & 54 \\
\hline Netherlands & 4.3 & 3.4 & 9.5 & 7.7 & 13.4 & 2.7 & 16.4 & 10.6 & 4.1 & 38 \\
\hline New Zealand & 2.4 & 4.0 & 7.3 & 4.8 & 17.5 & 1.1 & 11.2 & 5.7 & 2.0 & 19 \\
\hline Norway & 5.1 & 2.0 & 9.3 & 8.8 & 16.0 & 3.4 & 15.3 & 4.0 & 3.9 & 48 \\
\hline Portugal & 12.3 & -1.1 & 14.9 & 15.0 & 20.1 & 7.9 & 10.8 & 6.3 & 6.2 & 20 \\
\hline Singapore & 1.9 & 1.8 & 9.2 & 7.2 & 26.1 & 1.8 & 10.3 & 5.8 & 5.7 & 22 \\
\hline Spain & 7.2 & 3.3 & 14.9 & 10.3 & 19.7 & 5.5 & 15.1 & 7.5 & 5.8 & 54 \\
\hline Switzerland & 1.6 & 1.6 & 4.9 & 3.3 & 11.2 & 1.6 & 11.9 & 6.9 & 2.3 & 29 \\
\hline United Kingdom & 5.6 & 2.8 & 10.6 & 8.0 & 13.6 & 5.0 & 16.0 & 11.9 & 4.5 & 53 \\
\hline United States & 4.1 & 3.3 & 6.7 & 6.5 & 16.5 & 2.8 & 15.0 & 3.0 & 2.7 & 53 \\
\hline \multicolumn{11}{|c|}{ Emerging Markets (EM's) } \\
\hline \multicolumn{11}{|c|}{ Asia } \\
\hline Brazil & 365.8 & 4.2 & 76.9 & 75.6 & 29.2 & 721.0 & 17.2 & 93.1 & 93.0 & 34 \\
\hline India & 6.1 & 2.9 & 13.8 & 11.8 & 49.7 & 3.1 & 11.9 & 3.2 & 2.8 & 13 \\
\hline Malaysia & 3.6 & 4.0 & 13.6 & 10.1 & 31.2 & 3.0 & 16.5 & 8.0 & 7.1 & 44 \\
\hline Pakistan & 11.8 & 7.9 & 13.6 & 15.9 & 40.3 & 4.2 & 13.0 & 4.0 & 5.3 & 9 \\
\hline Philippines & 9.3 & 2.1 & 14.9 & 12.8 & 51.7 & 8.6 & 18.8 & 7.5 & 5.7 & 53 \\
\hline Thailand & 4.7 & 3.6 & 13.4 & 10.0 & 33.0 & 4.7 & 15.0 & 5.6 & 5.6 & 53 \\
\hline \multicolumn{11}{|l|}{ HighIne } \\
\hline Czech Republic & 4.4 & 2.6 & 7.7 & 7.5 & 20.4 & 3.4 & 15.6 & 9.1 & 5.7 & 21 \\
\hline Hungary & 12.2 & 2.9 & 12.8 & 11.4 & 19.1 & 9.2 & 10.6 & 8.0 & 7.5 & 23 \\
\hline Oman & 4.2 & 8.6 & 15.0 & 14.2 & 30.4 & 3.3 & 12.3 & 9.1 & 16.0 & 10 \\
\hline Qatar & 3.5 & 2.1 & 12.7 & 10.7 & 13.2 & 4.3 & 11.4 & 12.5 & 16.4 & 31 \\
\hline Saudi Arabia & 2.1 & 3.8 & 10.4 & 9.0 & 26.0 & 3.0 & 10.8 & 5.6 & 11.6 & 20 \\
\hline \multicolumn{11}{|l|}{ MIC } \\
\hline Algeria & 4.1 & 7.8 & 13.6 & 12.0 & 43.1 & 2.1 & 11.2 & 4.2 & 8.7 & 12 \\
\hline Argentina & 8.2 & 7.2 & 16.8 & 15.8 & 36.0 & 7.0 & 16.0 & 18.6 & 12.1 & 15 \\
\hline Colombia & 15.9 & 3.6 & 21.1 & 19.5 & 29.1 & 9.0 & 15.2 & 8.9 & 8.2 & 53 \\
\hline Costa Rica & 13.2 & 3.2 & 17.8 & 16.5 & 18.6 & 5.9 & 11.4 & 6.8 & 5.6 & 26 \\
\hline Jordan & 4.0 & 2.7 & 9.4 & 9.4 & 36.7 & 3.2 & 10.5 & 4.1 & 5.5 & 23 \\
\hline Mexico & 23.0 & 2.8 & 23.5 & 21.5 & 22.9 & 33.6 & 11.5 & 20.1 & 21.1 & 28 \\
\hline Poland & 14.6 & 2.1 & 16.7 & 14.3 & 25.0 & 19.0 & 9.9 & 11.4 & 11.8 & 24 \\
\hline Romania & 9.0 & 6.0 & 19.1 & 14.6 & 40.0 & 5.6 & 10.1 & 11.4 & 9.7 & 12 \\
\hline Turkey & 35.5 & 3.5 & 34.5 & 32.9 & 28.0 & 30.5 & 15.3 & 19.1 & 21.0 & 51 \\
\hline Uruguay & 41.2 & 4.0 & 33.3 & 34.2 & 28.5 & 31.9 & 17.2 & 21.4 & 24.9 & 41 \\
\hline \multicolumn{11}{|l|}{ SSA } \\
\hline Botswana & 8.6 & 3.8 & 16.8 & 12.6 & 21.8 & 1.7 & 11.1 & 15.7 & 7.0 & 19 \\
\hline Ghana & 29.3 & 3.6 & 27.3 & 26.2 & 44.9 & 28.4 & 15.0 & 13.2 & 15.4 & 50 \\
\hline Nigeria & 12.7 & 5.4 & 22.6 & 22.8 & 61.3 & 3.7 & 11.8 & 14.3 & 20.2 & 13 \\
\hline South Africa & 9.1 & 3.8 & 13.5 & 12.7 & 18.3 & 4.4 & 15.9 & 6.2 & 4.1 & 48 \\
\hline Uganda & 7.3 & 3.8 & 16.9 & 13.5 & 27.2 & 4.9 & 10.8 & 7.6 & 5.4 & 20 \\
\hline
\end{tabular}


Table A.3: Summary Statistics on the Monthly Data Set, 2000 to 2013

\begin{tabular}{|c|c|c|c|c|c|c|c|}
\hline Country & $\mathrm{N}$ & $\begin{array}{c}\text { Domestic } \\
\text { Food Inflation } \\
\text { (Mean) }\end{array}$ & $\begin{array}{c}\text { Domestic } \\
\text { Food Inflation } \\
\text { (Standard } \\
\text { Deviation) }\end{array}$ & Country & $\mathrm{N}$ & $\begin{array}{c}\text { Domestic } \\
\text { Food Inflation } \\
\text { (Mean) }\end{array}$ & $\begin{array}{c}\text { Domestic } \\
\text { Food Inflation } \\
\text { (Standard } \\
\text { Deviation) }\end{array}$ \\
\hline \multicolumn{4}{|c|}{ Advanced Economies (AE's) } & \multicolumn{4}{|c|}{ Emerging Markets (EM's) } \\
\hline Australia & 168 & 0.29 & 0.88 & Albania & 169 & 0.33 & 2.00 \\
\hline Austria & 168 & 0.21 & 0.68 & Algeria & 169 & 0.49 & 1.84 \\
\hline Belgium & 168 & 0.22 & 0.57 & Argentina & 169 & 0.82 & 1.41 \\
\hline Canada & 168 & 0.23 & 0.36 & Bahrain & 169 & 0.27 & 2.05 \\
\hline Cyprus & 168 & 0.26 & 1.77 & Bosnia \& Herzegov & 169 & 0.24 & 2.22 \\
\hline Czech Republic & 169 & 0.20 & 1.11 & Botswana & 169 & 0.76 & 0.80 \\
\hline Denmark & 168 & 0.19 & 0.57 & Brazil & 169 & 0.62 & 0.97 \\
\hline Estonia & 169 & 0.37 & 0.98 & Bulgaria & 169 & 0.40 & 1.86 \\
\hline Finland & 168 & 0.23 & 0.99 & Chile & 169 & 0.37 & 0.94 \\
\hline France & 168 & 0.16 & 0.54 & Colombia & 169 & 0.50 & 0.83 \\
\hline Germany & 168 & 0.16 & 0.64 & Costa Rica & 169 & 0.71 & 1.12 \\
\hline Greece & 168 & 0.21 & 1.15 & Croatia & 169 & 0.23 & 1.04 \\
\hline Hong Kong & 169 & 0.21 & 0.63 & Ecuador & 169 & 0.93 & 2.57 \\
\hline Iceland & 168 & 0.42 & 1.39 & Egypt & 169 & 1.10 & 1.71 \\
\hline Ireland & 168 & 0.10 & 0.48 & Ghana & 169 & 0.42 & 2.08 \\
\hline Is rael & 169 & 0.26 & 0.91 & Hungary & 169 & 0.49 & 1.30 \\
\hline Italy & 168 & 0.20 & 0.31 & India & 169 & 0.88 & 1.24 \\
\hline Japan & 168 & 0.01 & 0.67 & Iran & 169 & 1.88 & 2.40 \\
\hline Korea & 169 & 0.36 & 1.71 & Ivory Coast & 169 & 0.32 & 2.85 \\
\hline Malta & 168 & 0.35 & 1.15 & Jordan & 169 & 0.40 & 1.60 \\
\hline Netherlands & 168 & 0.14 & 0.64 & Kazakhstan & 169 & 0.72 & 1.00 \\
\hline New Zealand & 168 & 0.26 & 0.73 & Latvia & 169 & 0.45 & 1.24 \\
\hline Norway & 168 & 0.12 & 1.05 & Lebanon & 169 & 0.55 & 1.29 \\
\hline Portugal & 168 & 0.11 & 0.55 & Lithuania & 169 & 0.29 & 0.89 \\
\hline Singapore & 169 & 0.17 & 0.46 & Macao & 169 & 0.57 & 0.83 \\
\hline Slovakia & 169 & 0.22 & 0.95 & Macedonia & 169 & 0.17 & 1.28 \\
\hline Slovenia & 169 & 0.34 & 1.00 & Malaysia & 169 & 0.36 & 0.49 \\
\hline Spain & 168 & 0.24 & 0.39 & Mauritius & 169 & 0.47 & 0.73 \\
\hline Sweden & 168 & 0.14 & 0.58 & Mexico & 169 & 0.47 & 0.71 \\
\hline Switzerland & 168 & 0.04 & 0.55 & Montenegro & 169 & 0.26 & 1.11 \\
\hline Taiwan & 169 & 0.20 & 1.99 & Nigeria & 169 & 0.96 & 2.06 \\
\hline Turkey & 169 & 0.75 & 2.02 & Oman & 169 & 0.48 & 1.08 \\
\hline United Kingdom & 168 & 0.27 & 0.69 & Pakistan & 169 & 0.95 & 1.67 \\
\hline \multirow[t]{17}{*}{ United States } & 168 & 0.22 & 0.24 & Peru & 169 & 0.26 & 0.57 \\
\hline & & & & Philippines & 169 & 0.42 & 0.56 \\
\hline & & & & Poland & 169 & 0.24 & 1.01 \\
\hline & & & & Qatar & 169 & 0.20 & 0.76 \\
\hline & & & & Romania & 169 & 53.94 & 636.85 \\
\hline & & & & Russia & 169 & 0.88 & 0.93 \\
\hline & & & & Saudi Arabia & 169 & 0.41 & 0.79 \\
\hline & & & & Serbia & 169 & 0.95 & 2.11 \\
\hline & & & & South Africa & 169 & 0.57 & 0.60 \\
\hline & & & & Thailand & 169 & 0.36 & 0.78 \\
\hline & & & & Tunisia & 169 & 0.45 & 0.54 \\
\hline & & & & Uganda & 169 & 0.60 & 2.60 \\
\hline & & & & Ukraine & 169 & 0.76 & 1.60 \\
\hline & & & & United Arab Emirat & 169 & 0.39 & 1.05 \\
\hline & & & & Uruguay & 169 & 0.79 & 1.38 \\
\hline & & & & Venezuela & 169 & 2.25 & 2.14 \\
\hline & & & & Vietnam & 169 & 0.95 & 1.47 \\
\hline
\end{tabular}


Table A.4: Economies Included in the Analysis of Inflation Expectations

\begin{tabular}{llr}
\hline Country & Code Country & Code \\
\hline Argentina & 213 Mexico & 273 \\
Australia & 193 Netherlands & 138 \\
Brazil & 223 New Zealand & 196 \\
Bulgaria & 918 Norway & 142 \\
Canada & 156 Peru & 293 \\
Chile & 228 Philippines & 566 \\
China & 924 Poland & 964 \\
Colombia & 233 Romania & 968 \\
Croatia & 960 Russia & 922 \\
Czech Republic & 935 Singapore & 576 \\
Estonia & 939 Slovakia & 936 \\
Euro zone & 163 Slovenia & 961 \\
France & 132 South Korea & 542 \\
Germany & 134 Spain & 184 \\
Hong Kong & 532 Sweden & 144 \\
Hungary & 944 Switzerland & 146 \\
India & 534 Taiwan & 528 \\
Indonesia & 536 Thailand & 578 \\
Italy & 136 Turkey & 186 \\
Japan & 158 UK & 112 \\
Latvia & 941 Ukraine & 299 \\
Lithuania & 546 USA Venezuela & \\
Malaysia & & \\
\hline & & \\
\hline
\end{tabular}




\section{References}

Arezki, R., Hadri, K., Loungani, P., \& Rao, Y. (2014). Testing the Prebisch-Singer hypothesis since 1650: Evidence from panel techniques that allow for multiple breaks. Journal of International Money and Finance.

Auerbach, A.J., \& Gorodnichenko, Y. (2013). Output spillovers from fiscal policy. American Economic Review, 103(3), 141-46.

Batini, N., \& Nelson, E. (2005). The UK's rocky road to stability. Federal Reserve Bank of St. Louis Working Paper Series, 2005-020.

Blanchard, O. \& Galí, J. (2007). Real wage rigidities and the new Keynesian model. Journal of Money, Credit and Banking, 39(s1), 35-65.

Blinder, A. (1982). The anatomy of double-digit inflation in the 1970s. In R.E. Hall (Ed.), Inflation: Causes and Effects. Cambridge, MA: National Bureau of Economic Research.

Blinder, A. S., \& Rudd, J. B. (2008). The supply-shock explanation of the Great Stagflation revisited (No. w14563). Cambridge, MA: National Bureau of Economic Research.

DiCecio, R., \& Nelson, E. (2009). The great inflation in the United States and the United Kingdom: reconciling policy decisions and data outcomes (No. w14895). Cambridge, MA: National Bureau of Economic Research.

Grauwe, P. D., \& Polan, M. (2005). Is inflation always and everywhere a monetary phenomenon? The Scandinavian Journal of Economics, 107(2), 239-259.

Dwyer Jr, G. P., \& Hafer, R. W. (1999). Are money growth and inflation still related? Economic Review (Federal Reserve Bank of Atlanta), Q2, 32-43.

Ilzetzki, E.O., Reinhart, C.M., \& Rogoff, K.S. (2008). Exchange rate arrangements into the 21st century: Will the anchor currency hold? (Unpublished). Harvard University, Cambridge, Massachusetts.

Jorda, O. (2005). Estimation and inference of impulse responses by local projections. The American Economic Review, 95(1), 161-182.

Levin, A.T., Natalucci, F.M., \& Piger, J.M. (2004). The macroeconomic effects of inflation targeting. Federal Reserve Bank of St. Louis Review, 86, 51-80.

Loungani, P., \& Swagel, P. (2001). Sources of inflation in developing countries (IMF Working Paper 01/198). Washington, DC: International Monetary Fund.

Nickell, S. (1981). Biases in dynamic models with fixed effects. Econometrica: Journal of the Econometric Society, 1417-1426. 
Roger, S. (2010). Inflation targeting turns 20. Finance \& Development, 47(1).

Rogoff, K. (2003). Globalization and global disinflation. Economic Review-Federal Reserve Bank of Kansas City, 88(4), 45-80.

Stock, J.H., \& Watson, M.W. (2007). Why has U.S. inflation become harder to forecast? Journal of Money, Credit and Banking, 39(1), 3-33.

Teulings, C. N. \& Zubanov, N. (2014). "Is economic recovery a myth? Robust estimation of impulse responses. Journal of Applied Econometrics, 29, 497-514.

Wachter, S. (1979). Structuralism vs. monetarism: Inflation in Chile. In J. Behrman \& J. Hanson (Eds.), Short-Term Macroeconomic Policy in Latin America. Cambridge, MA: National Bureau of Economic Research.

Woodford, M. (2003). Interest and prices: Foundations of a theory of monetary policy. Princeton, NJ: Princeton University Press. 